\title{
Identifying New Approaches to U.S. Drug Policy Using Ownership, Location, and Internalization Factors
}

\author{
MARIANA SAENZ \\ Georgia Southern University* \\ ANTHONY G. BARILLA \\ Georgia Southern University
}

\begin{abstract}
Dunning's Eclectic Paradigm is used to assess the effectiveness and impact of U.S. drug prohibition policy on economic growth and political stability in Latin American countries as well as the decision making of Latin American Transnational Criminal Enterprises (TCE) in the cocaine-coca market. Results showed U.S. drug prohibition policy reduces the on-site supply but does not significantly reduce the transportation of cocaine and coca. U.S. drug prohibition policy also generated political instability for the region and revealed policy externalities that facilitated TCE expansion. Tougher U.S. drug prohibition policy advances TCE by amplifying the impact that unemployment and local wages have on increases in cocaine-coca production, and by limiting the impact of control of corruption and economic freedom on coca eradication. Our results signal that a site-specific approach accompanied with policies that improve the farmers' economic freedom, such as land formalization rights, and policies that lower unemployment rate facilitate effective U.S. drug prohibition policy.
\end{abstract}

Keywords: Prohibition; Latin America; Transnational Criminal Enterprises; Dunning's Eclectic Paradigm; Cocaine-Coca Market

JEL Classifications: H50, O50, H80

\section{Introduction}

The Americas are the world's main supplier of cocaine-coca as measured in terms of cultivation, manufacturing, eradication, and seizures. Colombia, Bolivia, and Peru account for virtually all of the world's coca bush cultivation and cocaine manufacturing (Organization of American States (OAS), 2013d). Colombia, the world's top manufacturer, accounts for 42 percent of the world's cocaine output, ${ }^{1} 64$ percent of the world's land under coca bush

(C) 2020 Mariana Saenz and Anthony G. Barilla. Licensed under the Creative Commons Attribution Noncommercial 3.0 Licence (http://creativecommons.org/licenses/by-nc/3.0/. Available at http: //rofea.org.

${ }^{1}$ Estimates of cocaine manufacturing is based on the area under cultivation, coca yield estimates, and cocaine lab efficiency. In 2015, the total potential manufacturing of 100 percent pure cocaine for the world was 995 metric tons and Colombia's production was 420 metric tons (Office of National Drug Control Policy (ONDCP), 2016). 
cultivation, ${ }^{2}$ and 52 percent of the world's land subject to coca bush eradication (United National Office of Drugs and Crime (UNODC), 2017b). ${ }^{3}$ The majority of drug transportation occurs in and around Latin American countries. In 2016, the United States Department of State estimated that the Mexico-Central America corridor accounted for 90 percent of the cocaine trafficked into the U.S. (Bureau for International Narcotics and Law Enforcement Affairs, 2017).

United States drug prohibition policy spending uses a three-fold approach: (1) domestic law enforcement, (2) reduction of transportation of illicit drugs and, (3) international efforts to reduce illicit drug supply (Office of National Drug Control Policy (ONDCP), 2014). This paper assesses the effectiveness and impact of U.S. drug prohibition policy approaches in reducing the transportation of cocaine-coca, along with the reduction of existing supplies of on-site cocaine production and the eradication of coca fields (currently or potentially used for production), using Dunning's Eclectic Paradigm, when dealing with Central, North, and South America. The U.S. drug prohibition approach depends on the geographic positioning of distribution outlets and production-sites associated with the cocaine market with the belief that increases in policy spending, aimed at restricting supply, have an indirect relationship with cocaine's availability.

International business literature has addressed locational decisions of multinational enterprises by applying Dunning's Eclectic Paradigm (Dunning, 1977, 1988a, 1996, 2009; Dunning and McKaig-Berliner, 2002). Dunning's paradigm identifies the Ownership, Location, and Internalization characteristics that influence multinational enterprises decisions. Ownership, Location, and Internalization characteristics are drawn from macroeconomic theories of trade, international capital movements and location, and microeconomic theories of industrial organization, innovation, and firm site-selection (Tolentino, 2001).

This paper extends the existing literature by applying Dunning's Eclectic Paradigm to Transnational Criminal Enterprises. Enderwick (2009, 2016) and Mudambi and Paul (2003), all used Dunning's Eclectic Paradigm (from a theoretical perspective) to explain the locational choices of Transnational Criminal Enterprises. We will take this approach one step further by empirically testing Dunning's Paradigm on illegal drug traffickers' locational behavior in the Americas. ${ }^{4}$ When Ownership, Location, and Internalization characteristics are used in conjunction with U.S. drug prohibition policy it allows the observation of governmental efforts

\footnotetext{
${ }^{2}$ The coca bush cultivation (hectares) reported for 2015 were: Colombia 159,000, Bolivia 36,500 and Peru 53,000 (Office of National Drug Control Policy (ONDCP), 2016).

${ }^{3}$ Eradication of coca bush (hectares) for 2015 were: Colombia 50,672, Peru 35,868, and Bolivia 11,020 (United National Office of Drugs and Crime (UNODC), 2017b).

${ }^{4}$ No prior research has empirically tested Dunning's Eclectic Paradigm in association with Transnational Criminal Enterprises.
} 
to regulate, destroy or inadvertently promote cocaine markets. Specifically, we investigate U.S drug prohibition policy's effectiveness at reducing cocaine-coca supply, its unintended effects of advancing Transnational Criminal Enterprises, and the impact of U.S. drug prohibition policy on the Latin American economy. Additionally, we will investigate whether Ownership, Location, or Internalization advantages exist to Transnational Criminal Enterprises, and if they result in strengthening or limiting effective U.S. drug prohibition policy. By identifying Transnational Criminal Enterprises' Ownership, Location, or Internalization characteristics, a national or local government could tailor a more effective drug prohibition policy.

This paper is organized as follows. Section 2 provides a literature review on U.S. drug prohibition policies. Section 3 discusses Dunning's Eclectic Paradigm as a framework to analyze the effectiveness of U.S. drug prohibition policy at reducing cocaine-coca supply, and its impact in Latin America. Section 4 and Section 5 discuss the variables used in the estimation and data sources, respectively. Section 6 outlines the empirical methodology which includes a discussion of missingness in the data. Section 7 provides a discussion of results. The final section presents our conclusions and policy implications.

\section{U.S. Drug Policies}

The United States has been involved in international drug control and has made efforts to decrease drug supplies since the beginning of the $20^{\text {th }}$ century (Rosen, 2015). United States drug prohibition started in 1914 when Congress passed the Harrison Act which banned opiates and cocaine (Redford and Powell, 2016). Alcohol prohibition quickly followed, and by 1918, with the passage of the Eighteenth Amendment, the U.S. was officially a "dry" nation.

With the Narcotics Drugs Import and Export Act of 1922, U.S. drug prohibition policy began to focus on combating the emergence of illegal criminal markets by controlling the flow of narcotics. In 1930, the Federal Bureau of Narcotics was created. Soon after the creation of the Federal Bureau of Narcotics, possession and transfer of marijuana was made unlawful under the Marihuana Tax Act of 1937 (Bonnie and Whitebread, 1970). ${ }^{5}$ In 1951, the Boggs Act was passed which increased drug related penalties and introduced mandatory minimum sentences for the possession and sale of narcotics (Gill, 2008). In 1956, the Narcotics Control Act increased the minimum sentences of crimes specified in the Boggs Act. In 1970, the Controlled Substances Act (CSA) was enacted into law by Congress and has become the foundation for "the modern drug war" that U.S. drug policy is fighting. In 1973, the newly formed Drug Enforcement Administration took over the enforcement of the CSA (United States Drug

\footnotetext{
${ }^{5}$ In 1933, the Twenty-First Amendment repealed the Eighteenth Amendment revoking alcohol prohibition.
} 
Enforcement Administration (DEA), 2020). The CSA was amended with the Anti-Drug Abuse Act of 1986 and 1988, which made the system more punitive to illicit drug offenders (Courtwright, 2004). ${ }^{6}$

United States drug control budgets have been mostly allocated to supply reduction efforts which include domestic law enforcement, international drug control efforts, and interdiction/disruption of illicit drug shipments. The estimates for the data used in this paper indicates that between 1995 and 2015, an average of about 70 percent of the U.S. drug control budget had been allocated to supply reduction efforts. However, according to Reuter and Kleiman (1986), U.S. illicit drug consumption is unresponsive to illicit drug supply prohibition efforts. Supply prohibition efforts have been found inefficient at raising the retail price of cocaine, which is a short-term indicator of the efficacy of supply reduction enforcement efforts to reduce illicit drug consumption (Caulkins and Reuter, 2010; Reuter and Kleiman, 1986).

Some early evidence indicates U.S. drug prohibition policy's inefficacy at reducing domestic cocaine supply and increasing U.S. cocaine retail prices. In terms of domestic law enforcement, between 1979 and 1989 the number of arrests for cocaine distribution increased (Reuter, 1991). The increase in domestic arrests did not offset the supply increases, given the fact that prices fell between 1979 and 1989. ${ }^{7}$ The increase in domestic arrests also reduced the effectiveness of law enforcement efforts by diversifying the sources of supply (Reuter, 1991).

In terms of international drug control efforts, reduction of illicit drugs at the source-country has also shown to be ineffective in raising the U.S. cocaine retail prices and reducing domestic supply (Caulkins and Reuter, 2010). Several reasons appear to indicate the ineffectiveness of U.S. drug prohibition policy at the source-country level: 1) production costs, 2) market concentration, 3) limitations on the application of U.S. policy overseas, and 4) responses of suppliers to U.S. drug prohibition policy. The cost of production at early stages of the production process (i.e. cultivating and refining) is a small percentage of the cocaine's retail price, which is estimated to be less than one percent of the U.S. retail price for cocaine (Caulkins and Reuter, 2010). Low market concentration (i.e. large number of market participants: large number of refining labs and farmers) at early stages of the cocaine production process also provides difficulties for the U.S. in reducing supply at the source-country (Caulkins and Reuter, 2010). A third reason is the limitation of applying U.S. drug prohibition policy overseas. Application of U.S. drug prohibition policy internationally is limited by the interests and capabilities of the source-country (Moore, 1990). Additionally, Moore (1990) indicates that in the past, U.S. prohibition policies have focused on crop control strategies such as eradication and crop substitution programs, but the prevalence of potential cultivating areas makes

\footnotetext{
${ }^{6}$ In 2010, many states started the process of legalizing or decriminalizing marijuana.

${ }^{7}$ The average price of cocaine in 1989 was 50 percent lower than in 1979.
} 
eradication policies a difficult task. Lastly, suppliers respond to U.S. drug prohibition policy by changing cultivation patterns. Roberts, Trace, and Klein (2004) assert that successful reduction in coca cultivation in Bolivia and Peru, resulted in increased coca cultivation in Colombia.

Similarly, U.S. drug interdiction policy has also been criticized for their "successes" in reducing supply and raising U.S. cocaine retail prices. Scholarly literature suggests that U.S. drug interdiction policy has not been effective because of: 1) smuggling costs, 2) substitution of smuggling routes, and 3) a focus on interdiction policy at finished inventories. Reuter (1992) reports that smuggling costs account for less than 10 percent of the U.S. cocaine retail prices, which means the size of the seizure must be large enough to affect the entrepreneur's assets, limiting the policy's financial impact on the narcotic traffickers (Caulkins and Reuter, 2010). Smuggling routes are also substituted in response to interdiction enforcement. Andreas (2000) suggests that U.S. drug interdiction efforts redirected air and sea smuggling routes to ground routes through Mexico. ${ }^{8}$ Additionally, Moore (1990) indicates that entrepreneurs also hedge against the risk of losing total shipments by dividing it into smaller shipments. Finally, Moore (1990) claims that interdiction policy is focused on finished inventories instead of disrupting trafficking networks.

Reuter and Kleiman (1986) point out that supply prohibition efforts cannot decrease consumption because they do not change consumer preferences. The solo approach of illicit drug supply reduction in Latin American countries in conjunction with the external erosions of their institutions has failed (Rosen, 2015; Youngers, 2013; Youngers and Rosin, 2005). U.S. drug policy's collateral damages is forcing changes in policy from simply concentrating on current drug control policy failures to crafting alternative approaches (Youngers, 2013), such as liberalizing the aspects of illicit drug control polices from the demand side (Organization of American States (OAS), 2013c). ${ }^{9}$

\section{Dunning's Eclectic Paradigm}

Dunning's Eclectic Paradigm identifies the advantages international businesses receive from Ownership, Location, or Internalization characteristics. Ownership variables are firm-specific advantages derived from resource control or firm ownership (McCann and Mudambi, 2004). Rugman and Gestrin (1993) describe Ownership advantages as the firm's competitiveproduction or marketing-based assets. Location advantages are derived from region-specific

\footnotetext{
${ }^{8}$ The South Florida Task Force, launched in 1982, targeted air and smuggling routes in the Southeast (Andreas, 2000).

${ }^{9}$ For example, in the U.S., decriminalization of marijuana for personal use in some states.
} 
advantages, including resource access, factor endowments, networks, and institutions (McCann and Mudambi, 2004; Rugman and Gestrin, 1993). Location advantages are immobile endowments firms have to use conjointly with their Ownership advantages (Dunning, 2000, 2001). Internalization advantages result from reducing transactional costs by internalizing transactions formerly carried out in the market (Buckley, 1993), as well as, the firm's ability to appropriate returns on its assets ownership and synchronize cross border activities (Cantwell and Narula, 2001).

Previous applications of Dunning's Eclectic Paradigm have been widely applied to legal operating enterprises (Dunning, 1996; Dunning and McKaig-Berliner, 2002). However, the relevance of Dunning's Eclectic Paradigm to Transnational Criminal Enterprises emanates from its similarities to multinational (legal) enterprises (Enderwick, 2009). Both multinational enterprises and Transnational Criminal Enterprises emphasize profits as their principal business objective and are resource mechanisms that respond to market and institutional failures. They both also attempt external growth strategies, and establish worldwide facilities for production, marketing, and distribution. Their production contributes to economic output and growth, and both have international supporting services. ${ }^{10}$ They also respond to changing global business environments accruing benefits from new distribution markets, increasing international income inequalities, and advanced communication and transportation technology (Enderwick, 2009).

Dunning's Eclectic Paradigm is used as our framework for investigating the connection between U.S. drug prohibition policy and Transnational Criminal Enterprises locational behavior in Latin America in relation to the cocaine-coca market. Specifically, we will empirically determine how Ownership, Location, and Internalization variables motivate Transnational Criminal Enterprises locational decisions in Latin America, assess the effectiveness of U.S. drug prohibition policy along with its relationship to the Ownership, Location, and Internalization variables. Moreover, we will evaluate the economic and political impact of U.S. drug prohibition policy in Latin America.

Applying Dunning's Eclectic Paradigm to a country is inconsistent with previous uses. However, given the illegality of Transnational Criminal Enterprises, the advantages for illegal enterprises stem from a country's characteristics and its competitive advantages. In the Transnational Criminal Enterprise framework Ownership advantages result from a country's history of narcotics cultivation, weak law enforcement, and "strategies of risk reduction including operating from a low risk home base" (Enderwick, 2016). In the case of Location advantages, Transnational Criminal Enterprises take advantage of the favorable conditions in

\footnotetext{
${ }^{10}$ Transnational Criminal Enterprises are more likely to pursue alliances instead of mergers or acquisitions, and they employ contract killers and money launders.
} 
SAENZ BARILLA New Approaches to U.S. Drug Policy

host countries. As Transnational Criminal Enterprises move operations to other countries, the location advantage relies on the new home-country advantages. For example, "legality" of the illicit drugs under domestic law can be easily exploited by Transnational Criminal Enterprises. In countries like Bolivia, the legal production of coca under domestic law has permitted the growth and relocation of organized drug traffickers (Enderwick, 2016). In this way, Location advantages to Transnational Criminal Enterprises stem from the new home-country opportunities. Internalization advantages for Transnational Criminal Enterprises come from the country's market failures, the benefit of maintaining secrecy, the lack of market prices for intermediate goods and services, and the lack of legal forms of compliance (Enderwick, 2016).

Other economic theory points to industry advantages stemming from a home-country competitive advantage. Porter (1990) asserts that a nation's competitive advantage is tied directly to industry advantages, since nations play an important role on how industries operate. "Porter's diamond" of national competitive advantage explains how nations provide a "favorable home base for companies to operate internationally" (Porter, 1990). In this context, Dunning's Eclectic Paradigm can also translate into the home country's characteristics that facilitate nations to be successful in particular industries. ${ }^{11}$

The evaluation of U.S. drug prohibition policy in Dunning's Eclectic Paradigm framework for Transnational Criminal Enterprises is done by estimating two main models. In the first model, illicit drug supply of cocaine-coca ${ }^{12}$ is estimated through direct (cultivation, potential

\footnotetext{
${ }^{11}$ Porter (1990)'s theory of a country's competitive advantage defines four different attributes for a nation that explains how industries, and therefore firms, are established and operated. The first attribute defined in Potter's theory is the nation's "factor conditions" referring to the nation's factors of production relevant to countries to compete in an industry. The second attribute, "demand conditions," refers to home market demand conditions that force companies to innovate and become more competitive. The third attribute, "related and supporting industries," refers to the presence of supporting and related industries (and that are internationally competitive) in the home country which facilitates mutually beneficial interactions to innovate. Last, the "firm strategy, structure, and rivalry" attribute, is defined as the country's atmosphere affecting how firms are established and operated. Dunning's Ownership, Location, and Internalization advantages can't exactly translate one-to-one to match Porter's theory attributes, but can be framed within Porter's theory. Dunning's Ownership advantages resemble the "factor conditions" attribute in Porter's theory. Dunning's Location advantages can be associated to Porter's "related and supporting industries" attribute. Related and supporting industries in the home country that are internationally competitive are affected by the host country characteristics. Host country characteristics affect home-country related and supporting industries interaction with other homecountry firms and their business strategies. Dunning's Internalization advantages can be associated to the "firm strategy, structure, and rivalry" attribute, as market failures driving internalization are circumstances affecting how industries operate.

${ }^{12}$ Figures on cultivation, production, eradication, and seizures depict the dominant role of the Americas in the illicit drug market. Ninety percent of the world's cocaine seizures were reported in the Americas, with production being concentrated in Colombia, Peru, and Bolivia (United National Office of Drugs and Crime (UNODC), 2010a, 2010b).
} 
production, and eradication ${ }^{13}$ ) and indirect indicators (transport seizures). Model 1 (equation 1 below) is used to empirically determine how Ownership, Location, and Internalization variables motivate Transnational Criminal Enterprises locational decisions in the Americas. In addition, Model 1 is used to assess the effectiveness of the U.S. drug prohibition policy and its relationship to the Ownership, Location, and Internalization variables. Specifically, for Model 1 , each $i^{\text {th }}$ illicit drug supply indicator ( $i=1$ for seizures, $i=2$ for cultivation, $i=3$ for potential cocaine production, and $i=4$ for eradication) in the $j^{\text {th }}$ country at time $t$ is defined as,

$$
\begin{aligned}
& \log \left(\text { Supply Indicator }_{i j t}\right)=\beta_{0}+\beta_{1} \log \left(\text { Prohibition }_{t}\right)+\beta_{2}\left(\log \left(\text { Prohibition }_{t}\right) \times x_{l j t}\right) \\
& +\sum_{l} \beta_{3 l} x_{l j t}+\beta_{4} \log (\text { U.S. Cocaine Price } t)+\beta_{5} \text { Big Country }_{j}+\varepsilon_{i j t}
\end{aligned}
$$

where Prohibition $t_{t}$ measures U.S. drug prohibition policy, $x_{l j t}$ represents the $l^{\text {th }}$ Ownership, Location, or Internalization variable, U.S. Cocaine Price ${ }_{t}$ is the U.S. cocaine retail price index, Big Country $_{j}$ is a dummy variable taking the value of one if the $j^{\text {th }}$ country is a main producer of cocaine-coca and zero otherwise. The unobserved disturbances for each observation in equation (1) are represented by $\varepsilon_{i j t}$. The interaction of the U.S. drug prohibition policy with each of the Ownership, Location, and Internalization variables (i.e. $\log \left(\right.$ Prohibition $\left.\left._{t}\right) \times x_{l j t}\right)$, allows us to identify how Ownership, Location or Internalization variables strengthen or limit U.S. drug prohibition policy. In addition, the interaction terms allow us to assess U.S. drug prohibition policy's unintended effect at advancing Transnational Criminal Enterprises.

The second model (equations 2 and 3 below) evaluates the economic and political impact of U.S. drug prohibition policy in Latin America. Equations 2 and 3 estimate the impact of U.S. drug prohibition policy on real GDP growth and political stability, after controlling for the impacts of the Ownership, Location, and Internalization variables that determine Transnational Criminal Enterprises locational decisions. The simultaneous regression of real GDP growth and political stability is defined as,

$$
\begin{aligned}
& \text { Real GDP Growth } \text { jt }_{1}=\theta_{0}+\theta_{1} \log \left(\text { Prohibition }_{t}\right)+\sum_{l} \theta_{2 l} x_{l j t}+ \\
& \theta_{3} \log \left(\text { U.S. Cocaine Price }{ }_{t}\right)+\theta_{4} \text { Big Country }_{j}+\varepsilon_{1 j t}
\end{aligned}
$$

\footnotetext{
${ }^{13}$ The degree of eradication also reflects the extent by which authorities prioritize coca eradication (United National Office of Drugs and Crime (UNODC), 2017c).
} 
SAENZ BARILLA New Approaches to U.S. Drug Policy

Political Stability $_{j t}=\delta_{0}+\delta_{1} \log \left(\right.$ Prohibition $\left._{t}\right)+\sum_{l} \delta_{2 l} x_{l j t}+$

$$
\delta_{3} \log (\text { U.S. Cocaine Price } t)+\delta_{4} \text { Big Country } y_{j}+\varepsilon_{2 j t}
$$

where $\varepsilon_{1 j t}$ and $\varepsilon_{2 j t}$ are the unobserved disturbances for the real GDP growth and political stability equations, respectively. The simultaneous regression of real GDP growth and political stability allows us to consider the correlation among real GDP growth and political stability.

\section{Definition of Variables}

Table 1 describes and lists the illicit drug supply and impact indicators. Cocaine-coca seizures from both Latin America and the U.S. are used to signal regional drug availability. Cocainecoca market production is measured using coca cultivation and potential cocaine production. ${ }^{14}$ On-site seizures are measured using coca eradication. Real GDP growth and political stability are the impact indicators measuring U.S. drug prohibition policy impacts in Latin America.

U.S. drug prohibition policy, focusing on transport seizures and international illicit drug control expenditures, along with the Ownership, Location, and Internalization variables are described in Table 2. U.S. drug prohibition policy focusing on transport seizures is measured using interdiction expenditures directed at disrupting drug distribution profits by the interruption of illicit drug transportation into the U.S. (Office of National Drug Control Policy (ONDCP), 2013). International illicit drug control spending includes the eradication of crops, prosecution of traffickers, elimination of processing capabilities, promotion of alternative crops, and the investigation of money laundering or financial crime activities (Office of National Drug Control Policy (ONDCP), 2013). Prohibition is expected to negatively impact Transnational Criminal Enterprises by reducing the supply of illicit drugs. Mejia and Restrepo (2014) report a significant reduction, approximately 200 to 500 metric tons, in Colombia's net cocaine supply as result of successful interdiction policies in 2007. In addition, prohibition can cause input prices to increase. The United Nations Office on Drugs and Crime (UNODC) reported that Peru's coca eradication efforts in 2013 caused the average price of dried coca leaf to increase by 30 percent (United National Office of Drugs and Crime (UNODC), 2015). Unfortunately, prohibition also positively impacts Translational Criminal Enterprises by increasing illicit drug retail prices. ${ }^{15}$

\footnotetext{
${ }^{14}$ Potential cocaine production is defined as the amount of cocaine that would be produced yearly if all the area under coca cultivation was converted into 100 percent pure cocaine hydrochloride (United National Office of Drugs and Crime (UNODC), 2010b).

${ }^{15}$ For example, wholesale prices for cannabis users in the western U.S. went from $\$ 3,500$ dollars per pound with prohibition to an estimated $\$ 2,000$ dollars per pound with partial illicit drug prohibition (Caulkins, 2014).
} 
Table 1. Descriptive Statistics - Independent Variables

\begin{tabular}{|c|c|c|c|c|}
\hline Dependent Variables & No. Obs. & Description & Mean & Std. dev. \\
\hline \multicolumn{5}{|c|}{ Illicit Drug Supply Indicators } \\
\hline $\begin{array}{l}\text { Cocaine-Coca } \\
\text { Seizures }\end{array}$ & 359 & $\begin{array}{l}\text { Total drug seizure of cocaine- } \\
\text { coca (kilograms) }\end{array}$ & 137,946 & 371,350 \\
\hline Coca Cultivation & 60 & $\begin{array}{l}\text { Net coca cultivation for main } \\
\text { coca producers (i.e. Colombia, } \\
\text { Bolivia, and Peru) (hectares) }\end{array}$ & 63,614 & 44,381 \\
\hline $\begin{array}{l}\text { Potential Cocaine } \\
\text { Production }\end{array}$ & 60 & $\begin{array}{l}\text { Potential pure cocaine } \\
\text { production for main coca } \\
\text { producers (i.e. Colombia, } \\
\text { Bolivia, and Peru) (metric } \\
\text { tons) }\end{array}$ & 252 & 134 \\
\hline Coca Eradication & 60 & $\begin{array}{l}\text { Coca bush eradication for } \\
\text { main coca producers } \\
\text { (Colombia, Bolivia, and Peru) } \\
\text { (hectares). }\end{array}$ & 46,524 & 62,408 \\
\hline \multicolumn{5}{|l|}{ Impact Indicators } \\
\hline Real GDP Growth & 360 & $\begin{array}{l}\text { Growth of real GDP given in } \\
\text { constant } 2011 \text { U.S.D }(\%)\end{array}$ & 3.5 & 3.35 \\
\hline Political Stability ${ }^{a}$ & 306 & $\begin{array}{l}\text { Political Stability and absence } \\
\text { of violence/terrorism (index; } \\
\text { range }-2.5 \text { and } 2.5 \text { ) }\end{array}$ & -0.3 & 0.67 \\
\hline
\end{tabular}

${ }^{a}$ Political stability and absence of violence/terrorism measures perceptions of the likelihood of political instability and/or politically-motivated violence, including terrorism (The World Bank, 2017b). Higher values of the index represent countries with greater political stability.

Transnational Criminal Enterprises often use prohibition as an Ownership, Location, and Internalization advantage. Prohibition as an Ownership advantage is associated with the effect of regulation on how Transnational Criminal Enterprises manage their business operations. As firms become more globalized, the ownership advantage relies more on their ability to manage and coordinate a network of geographical activities (Dunning, 1988b). Government regulation (or prohibition) affects Transnational Criminal Enterprises by lowering the marginal cost and raising the marginal benefits to violence because their transactions cannot use the legal and judicial system (Miron and Zwiebel, 1995). Governments that fail to enforce property rights in an illegal market, decrease costs of illegal methods of enforcement, leading to more private and less public enforcement (Mudambi and Paul, 2003). 
SAENZ BARILLA New Approaches to U.S. Drug Policy

Table 2. Descriptive Statistics - Dependent Variables

\begin{tabular}{|c|c|c|c|c|}
\hline & No. Obs. & Description & Mean & Std. Dev. \\
\hline \multicolumn{5}{|l|}{ Prohibition Variables } \\
\hline $\begin{array}{l}\text { U.S. Interdiction } \\
\text { Expenditure }\end{array}$ & 20 & $\begin{array}{l}\text { U.S. expenditure on interdiction } \\
\text { illicit drug control (millions of } \\
\text { constant } 2011 \text { U.S.D) }\end{array}$ & 2,887 & 645 \\
\hline $\begin{array}{l}\text { U.S. International } \\
\text { Expenditure }\end{array}$ & 20 & $\begin{array}{l}\text { U.S. expenditure on international } \\
\text { illicit drug control (millions of } \\
\text { constant } 2011 \text { U.S.D) }\end{array}$ & 1,474 & 571 \\
\hline \multicolumn{5}{|l|}{ Location Variables } \\
\hline Unemployment Rate & 360 & $\begin{array}{l}\text { Unemployment, total ( } \% \text { of total } \\
\text { labor force) }\end{array}$ & 7.6 & 3.69 \\
\hline $\begin{array}{l}\text { Relative Minimum } \\
\text { Wage }\end{array}$ & 338 & $\begin{array}{l}\text { Country's monthly relative } \\
\text { minimum wage (local minimum } \\
\text { wage in constant } 2011 \text { U.S.D as a } \\
\text { percentage of U.S. minimum } \\
\text { wage in constant } 2011 \text { U.S.D; \%) }\end{array}$ & 25.57 & 21.68 \\
\hline $\begin{array}{l}\text { Human Capital } \\
\text { Index }\end{array}$ & 360 & $\begin{array}{l}\text { Human capital index based on } \\
\text { years of schooling and returns to } \\
\text { education (Index) }\end{array}$ & 2.46 & 0.44 \\
\hline Openness & 359 & Trade (\% of GDP) & 62.87 & 31.12 \\
\hline Distance & 360 & $\begin{array}{l}\text { Distance from US centroid to } \\
\text { country's centroid (miles) }\end{array}$ & 3,185 & 1,489 \\
\hline \multicolumn{5}{|l|}{ Internalization variables } \\
\hline Economic Freedom & 360 & $\begin{array}{l}\text { Index of Economic Freedom } \\
\text { (Index; range } 0 \text { (repressed) to } \\
100 \text { (free)) }\end{array}$ & 63.06 & 8.74 \\
\hline Tariff Rate & 334 & $\begin{array}{l}\text { Weighted mean applied tariff, all } \\
\text { products }(\%)\end{array}$ & 6.39 & 3.58 \\
\hline Internet Access & 360 & $\begin{array}{l}\text { Individuals using the internet } \\
\text { (\% of population) }\end{array}$ & 20.96 & 20.35 \\
\hline \multicolumn{5}{|l|}{ Instrumental Variable } \\
\hline IV & & $\begin{array}{l}\text { Political Administration } \\
\text { (Republican party }=1 ; 0 \\
\text { otherwise) }\end{array}$ & 0.4 & 0.49 \\
\hline \multicolumn{5}{|l|}{ Demand Proxy } \\
\hline U.S. Cocaine Price & 20 & $\begin{array}{l}\text { Average U.S. Cocaine retail price } \\
\text { index adjusted for purity (base } \\
\text { year 2011) }\end{array}$ & 83 & 26 \\
\hline
\end{tabular}


Prohibition as a Location advantage is associated with institutional failures. Wealth transfers from the Transnational Criminal Enterprise to policy makers are indicative of political rent-seeking behavior, oftentimes result from institutional failures and policies. This behavior is associated with governmental regulation which forces changes to the enterprise's operations (Butler and Castelo, 1998). Other forms of regulation such as domestic market prohibitions, incentivize Transnational Criminal Enterprises to locate in jurisdictions with lower levels of state policing and political risks (Mudambi and Paul, 2003). Successful prohibition also drives Transnational Criminal Enterprises to different locations to substitute transit routes and relocate production sites (Enderwick, 2016).

Prohibition as an Internalization advantage is associated with the effects of regulation on prices. Governmental regulation dealing with market failures oftentimes distorts prices which incentivizes the internalization of Transnational Criminal Enterprises' activities (Mudambi and Paul, 2003). Prohibition also incentivizes Transnational Criminal Enterprises to internalize their functions in order to reduce the risk of apprehension and punishment, such as with Peruvian coca traffickers, whom increased their profits by internalizing their cocaine production processes because of prohibition (Mudambi and Paul, 2003). Strong governmental regulation makes it difficult to find market prices for intermediate goods and services, encouraging Internalization advantages (Enderwick, 2009; Mudambi and Paul, 2003). Internalization is also an advantage when secrecy is critical, especially when strong regulation rescinds government supported claims to the illegal good and related property (Mudambi and Paul, 2003).

Prohibition is expected to have a negative impact on economic growth. Public institutions face increased costs when dealing with health concerns caused by drug use, increased drug violence, and corruption. Large amounts of public resources must also be allocated for any drug prohibition policy to work. Moreover, concentrating governmental resources into a small portion of the economy robs other economic sectors of potential governmentally sponsored economic development. ${ }^{16}$ In Brazil, between 2007 and 2012, the population of people incarcerated for drug trafficking increased by 123 percent (Organization of American States (OAS), 2013a). In the U.S. the 2007 economic cost of illicit drug use, lost productivity, and crime was estimated at $\$ 193$ billion dollars (National Drug Intelligence Center, 2011).

Prohibition is also expected to have a negative impact on political stability. Similarly to the U.S. alcohol prohibition of the 1920 s, drug prohibition moves transactions into the shadow economy where criminal enterprises can profit and undermine a country's institutions. Rosen (2015) asserts that illicit financial flows (e.g. money laundering) associated with drug trafficking have penetrated legitimate economic institutions while undermining legitimate

\footnotetext{
${ }^{16}$ In Mexico, the government expenditure to combat drug trafficking in relation to GDP, is three times larger than the amount spent by the U.S. (Organization of American States (OAS), 2013a).
} 
social and political systems. Furthermore, the illicit drug industry oftentimes serves as a conduit for wealth increases by politicians and persons in power as institutional corruption creates a lack of transparency and accountability (Organization of American States (OAS), 2013a). ${ }^{17}$ Political instability also occurs when a lack of legal job opportunities and excessive prohibition spending takes away potential funds needed for a country's growth and development (Thornton, 1991).

Ownership advantages for Transnational Criminal Enterprises are reduced or negated by the enterprises' illegal status along with the associated risk of property seizures (Enderwick, 2009). Ownership advantages also improve the illegal enterprise's ability to operate effectively by lowering risk and reducing the likelihood of detection (Enderwick, 2009). The Ownership variable is captured by the control-of-corruption index (see Table 2). The control-of-corruption index measures the scope by which public power is used for private gain (The World Bank, 2017b). The effect of the control-of-corruption index on Transnational Criminal Enterprises locational decision is ambiguous. In countries with high levels of corruption (i.e. low values for the control-of-corruption index), Transnational Criminal Enterprises become influential on a country's regulatory practices and legislation, reduce risk of interdiction, and facilitate drug trafficking (Berlusconi et al., 2017; Giommoni et al., 2017). Mudambi and Paul (2003) assert that Ownership advantages result from Transnational Criminal Enterprises controlling resources providing means to coerce others, making the control of resources rather than the direct ownership, the principal source of their advantage. However, weak governments make corruption levels disadvantageous to Transnational Criminal Enterprises by increasing the cost of doing business (e.g. increases in the value of bribes) (Mudambi and Paul, 2003). Thus, greater values for the control-of-corruption index is advantageous to Transnational Criminal Enterprises by lowering the cost of doing business, but it is disadvantageous by increasing risks in the transportation and production of illegal drugs. Greater control of corruption is also expected to spur economic growth and generate political stability. Latin American countries spend at least 10 percent of their GDP dealing with corruption (United National Office of Drugs and Crime (UNODC), 2008) and the control of corruption indicates a level of governmental effectiveness and rule of law. ${ }^{18}$

Transnational Criminal Enterprises can gain access to a country's illegal drug supply and demand by exploiting Location advantages (Enderwick, 2009), such as unemployment rate,

${ }^{17}$ In 2009, the director of the national police in Guatemala and others under his command were fired after large amounts of confiscated cocaine went missing (United National Office of Drugs and Crime (UNODC), 2010a).

${ }^{18}$ For the data used in this research, the correlation between the control-of-corruption index, government effectiveness, and rule of law is 0.9 . 
relative minimum wage, human capital, openness, and distance (see Table 2). The local unemployment rate and the human capital index are considered local endowments, while local wages are considered an input cost advantage (McCann and Mudambi, 2004; Rugman and Gestrin, 1993). The Location variable, unemployment rate, is expected to give locational advantages to Transnational Criminal Enterprises, because higher unemployment rates facilitate the growth of organized crime (Sung, 2004). Increased unemployment significantly increases expected illegal earnings (Uggen and Thompson, 2003) and many unemployed urban youths are recruited by gangs (Howell and Decker, 1999; Spergel, 1991). Higher unemployment rates are expected to be detrimental for economic growth and political stability.

The relative minimum wage, is the ratio of the minimum wage between Latin American countries and the U.S. Low wages are advantageous to Transnational Criminal Enterprises because they lead to a greater likelihood of corruption (Cadot, 1987). Uggen and Thompson (2003) found that during the 1970s, a recessionary period in the U.S., as legal earnings decreased expected illegal earnings increased. Lower local wages decrease the opportunity costs of legal employment and in some population cohorts generate higher crime rates (Gould et al., 2002). Low wages can also be a disadvantage to Transnational Criminal Enterprises when affecting the worker's productivity. Greater performance related payments can spur productivity and increase output (Booth and Frank, 1999). Higher minimum wages can also be limiting to economic growth and might increase political instability if higher wages increase unemployment (Gould et al., 2002; Siebert, 1997).

The human capital index measures the country's average years of schooling and educational rate of return (Feenstra et al., 2013). Reduced human capital levels give locational advantages to Transnational Criminal Enterprises because low skill levels imply a low opportunity cost of committing crime (Lochner, 2004). Lochner (2004) also finds a significant effect of education on property and violent crimes for low skill workers. Human capital increases are expected to positively affect economic growth and political stability. ${ }^{19}$

Openness captures the advantages that globalization gives to Translational Criminal Enterprises. Globalization can increase income inequality allowing Translational Criminal Enterprises to target marginalized segments of the population (Enderwick, 2009). For example, countries suffering increasing inequalities may offer Transnational Criminal Enterprises a marginalized labor force attracted to illegal activities. Greater openness has also been found to increase economic growth (Singh, 2010), but its effect on political stability is ambiguous. The effect of openness on political stability depends on the country's trading arrangements and trade policy (Kim, 1996; Mansfield and Pevehouse, 2000).

\footnotetext{
${ }^{19}$ The net effect of increased human capital levels could be detrimental to economic growth if a brain drain of higher educated individuals occurs.
} 
The last Location variable, distance, is measured as the distance from the U.S. centroid to each country's centroid. The variable distance is included to capture geographical proximity to the U.S. market. Geography creates a Location advantage when drug flows increase from lower to higher income countries (Enderwick, 2009) affecting the countries' political stability. ${ }^{20}$ "Transnational Criminal Enterprises contribute to political, economic, and social instability through corruption payments" (Enderwick, 2016), and political instability has been found to reduce economic growth (Alesina et al., 1996).

The Internalization variables include economic freedom, tariff rate, and internet access (see Table 2). Economic freedom measures a country's average score for its ratings for rule of law (i.e. property rights and judicial effectiveness), government size, regulatory efficiency (i.e. business freedom, labor freedom, and monetary freedom), and open markets (The Heritage Foundation, 2018). We expect lower economic freedom to encourage the development of the shadow economy and other illicit activities, which promotes Transnational Criminal Enterprises. Enste (2010) discovered that labor and product market regulations, for twenty-five OECD countries, were the primary causes for the development of shadow economies. Lack of property rights also increase the size of illicit economies. Muñoz-Mora et al. (2018) found that decreases in a land formalization index (i.e. worse property rights) significantly increases land area allocation to coca crops. Tariff rates ${ }^{21}$ are measured by the country's weighted tariff rate for all products and capture the effect that market liberalization has on Transnational Criminal Enterprises. Transnational Criminal Enterprises are affected by market liberalization as more trade facilitates the laundering of illicit drug proceeds through Trade Based Money Laundering (Financial Action Task Force (FATF), 2006). Internet access is measured as the percentage of individuals in the total population who have used the internet in the past three months and it captures the use of technology to internalize transactions and expand market opportunities for Transnational Criminal Enterprises (Enderwick, 2009, 2016). An increasing proportion of drug users are obtaining drugs over the darknet, and the internet has also reshaped relationships between suppliers, intermediaries, and buyers in drug trafficking (Lavorgna, 2014; United National Office of Drugs and Crime (UNODC), 2017b). Greater restrictions to voluntary

\footnotetext{
${ }^{20}$ The distance variable is highly correlated with other variables used in the estimation. Therefore, it was only included in equations (2) and (3). These equations measure the impact of the U.S. drug prohibition policy in Latin America. The closer in distance to the U.S., the more likely a country experiences political instability, because of the illicit drug flow to the U.S.

${ }^{21}$ Tariff rates were included as a proxy for international market regulation. Tariffs are expected to indicate difficulties in moving products internationally. There is evidence of Transnational Criminal Enterprises using legitimate commerce to smuggle illicit drugs. Boyum and Reuter (2005) point that in the early 1990s cocaine had been smuggled through legitimate commerce, a practice that became more common with the North American Free Trade Agreement (NAFTA). Transnational Criminal Enterprises therefore should be negatively impacted by tariff rates, because countries with high tariffs generally impose more restrictions and a greater cost of allowing products to enter their country.
} 
exchanges (i.e. lower economic freedom and higher tariff rates) and less accessibility to technology are also expected to be detrimental to economic growth and political stability.

In addition to the U.S. drug prohibition policy and the Ownership, Location, and Internalization variables, Table 2 also lists an instrumental variable used to identify U.S. political administration's views toward illicit drug control (prohibition) and a proxy for U.S. cocaine demand. The instrumental variable takes a value of one for Republican administrations and zero otherwise. Republican administrations are expected to have tougher prohibition policies and allocate greater funding to illicit drug control. ${ }^{22}$ Finally, the U.S. cocaine retail price index adjusted for purity is used as a proxy of demand.

\section{Data}

Data from 1996-2015 is used in the analysis for Argentina, Bolivia, Brazil, Chile, Colombia, Costa Rica, Ecuador, El Salvador, Guatemala, Honduras, Mexico, Nicaragua, Panama, Paraguay, Peru, United States, Uruguay, and Venezuela. Cocaine-coca seizure data was obtained from the United National Office of Drugs and Crime (UNODC) (2017a), and data for coca cultivation and potential pure cocaine (hydrochloride) production was obtained from the Office of National Drug Control Policy (ONDCP) (2016). Coca eradication data including both manual and spraying eradication methods were obtained from the ONDCP and the UNODC (Office of National Drug Control Policy (ONDCP), 2016; United National Office of Drugs and Crime (UNODC), 2010a, 2011, 2015, 2017a). Data for U.S. interdiction expenditures (cocaine-coca transit reductions) and international expenditures (production site supply limitations) were taken from the National Drug Control Strategy budget summary reports for the 1998 fiscal year through the 2017 fiscal year (Office of National Drug Control Policy (ONDCP), 2018). ${ }^{23}$

The political stability and control-of-corruption index were obtained from the Worldwide Governance Indicators database (The World Bank, 2017b). Minimum wage data was obtained from the International Labour Organization (ILO), DatosMacro, the national institute of Bolivian statistics, and the national bank of Colombia (Banco de la República de Colombia, 2018; Datosmacro, 2018; Instituto Nacional de Estadística (INE), 2018; International Labour Organization (ILO), 2018). The Penn World Table version 9.0 provided the human capital

\footnotetext{
${ }^{22}$ Our data shows Republican administrations spent 2.6 percent more on international and interdiction policies than Democratic administrations. Discussion of the exclusion, exogeneity, and relevance are presented in the results section.

${ }^{23}$ 1996-2015 final expenditure data was reported from several federal agencies but during that time frame some agencies were terminated or merged, while other agencies/programs were added to the National Drug Control Budget. For consistency, we used the interdiction and international expenditures from those agencies/programs that were included in the 2012 fiscal year budget (Office of National Drug Control Policy (ONDCP), 2011).
} 
SAENZ BARILLA New Approaches to U.S. Drug Policy

index (Feenstra et al., 2013). The distance measures were obtained from the geographic data provided by the Portland State University Department of Economics (Porland State University, 2009). The Index of Economic Freedom was obtained from the Heritage Foundation's 2018 report (The Heritage Foundation, 2018). Real GDP statistics, the unemployment rate, openness, tariff rate, and internet access variables were obtained from the World Development Indicators database (The World Bank, 2017a). The U.S. cocaine retail price index adjusted for purity was taken from the World Drug Report 2019 (United Nations, 2019).

\section{Econometric Estimation}

Two approaches, a Maximum Likelihood with Missing Values estimator (MLMV) and Multiple Imputation analysis, were used to deal with missing values in the data when estimating the impact of U.S. drug prohibition policy on the illicit drug supply indicators, real GDP growth, and political stability. MLMV is used in the estimation of coca cultivation (equation 1 for $i=2$ ), potential cocaine production (equation 1 for $i=3$ ), and coca eradication (equation 1 for $i=4$ ), using Stata's Structural Equation Modeling (SEM) command. The MLMV method assumes joint normality of all variables and allow us to obtain more efficient estimates when missing values are Missing at Random (MAR) (StataCorp, 2017). MLMV estimates the log-likelihood of missing data by grouping data according to missing value patterns (StataCorp, 2017).

Multiple Imputation analysis is used to estimate crop seizures (equation 1 for $i=1$ ), and the effect of prohibition (equations 2 and 3) in Latin American countries. ${ }^{24}$ The multiple imputation approach minimizes bias, maximizes the use of available information, and obtains appropriate estimates of uncertainty (UCLA: Statistical Consulting Group, 2018b). There are three steps in the multiple imputation method: 1) imputation, 2) analysis, and 3) pooling. In the imputation step, the missing values are replaced with $m$ multiple sets ${ }^{25}$ of estimated values to obtain $m$ complete data sets. Stata's multiple imputation (MI) command was used to impute missing values using chained equations. The estimation of missing data by chained equations uses separate conditional distributions for each imputed variable (UCLA: Statistical Consulting

\footnotetext{
${ }^{24}$ The MLMV approach is not used because the assumption of multivariate normality of all variables does not hold. The MLMV is used for the estimation of cultivation, potential cocaine production, and eradication because it is easier to implement and produces similar results to those of multiple imputation without requiring imputed values (UCLA: Statistical Consulting Group, 2018b).

${ }^{25}$ Twenty-five multiple sets were imputed for the estimation of equation 1 for $\boldsymbol{i}=1$ (i.e. seizures), using Data Set 1 . Fifty multiple sets were imputed for the estimation of equations 2 and 3 (i.e. real GDP growth and political stability) using Data Set 3 . The number of imputations were chosen so that the number of imputations were higher than the highest Fraction of Missing Information as discussed in UCLA: Statistical Consulting Group (2018b).
} 
Group, 2018b). ${ }^{26}$ In the analysis step, each of the $m$ data sets is used to perform the regression analysis. In step three, pooling, the coefficients and standard errors are adjusted to reflect the uncertainty of the imputed values. Maximum Likelihood estimators and robust standard errors were estimated in each regression. Goodness of fit statistics (i.e. R-Squared) were calculated using the method outlined by the Institute for Digital Research and Education (IDRE) (UCLA: Statistical Consulting Group, 2018a). ${ }^{27}$

Consistent estimates require explanatory variables to be independent of the unobserved time-varying shocks and countries heterogeneity. The Correlated Random Effects (CRE) framework was used to account for the correlation between the explanatory variables and the countries unobserved heterogeneity (Saenz and Thompson, 2017). The CRE framework was implemented by including the average of time-varying explanatory variables as covariates in each estimated regression. A Control Function (CF) approach was used to control for the correlation between the U.S. drug prohibition policy variable and the time-varying shocks that affect the Transnational Criminal Enterprises locational decisions. The $\mathrm{CF}$ approach includes the estimated residuals from the prohibition policy regression, ${ }^{28}$ as well as the explanatory variables, in the estimation of equations (1), (2), and (3). Significance of the differential effects of prohibition were assessed by using a significant-joint hypothesis of the prohibition and its interaction effect. ${ }^{29}$

Highly correlated variables were excluded from the analysis to avoid multicollinearity. A Variance Inflation Factor (VIF) for each variable was estimated after excluding highly correlated variables (see Table 3 below) for the three data sets. Data Set 1 includes observations for the Latin American countries and the U.S. to estimate cocaine-coca seizures. Data Set 2 includes the observations for the main cocaine-coca producers (i.e. Colombia, Peru, and Bolivia) and it is used in the estimation of coca cultivation, potential cocaine production, and

\footnotetext{
${ }^{26}$ The Stata's command used was "mi impute chained" using predicted mean matching (PMM) as the option for the univariate imputation method. Stata's PMM option matches the missing value to the observed value with the closest linear prediction. The PMM is used because it maintains the distribution of the observed values in the missing part of the data (StataCorp, 2013). The truncated regression option was used in the imputation of tariff rate for the estimation of real GDP growth and political stability because it produced a distribution of the imputed values closer to the distribution of the observed values in comparison to PMM.

${ }^{27}$ IDRE established methodology when using multiple imputation to calculate the R-Squared.

${ }^{28}$ The prohibition variable was regressed on the instrumental variable, and same set of covariates and observations used to estimate each of the $\boldsymbol{i}^{\boldsymbol{t}}$ illicit drug supply indicator (equations 1) and impact indicators (equations 2 and 3).

${ }^{29}$ Joint hypothesis are based on F-statistic tests and are less affected by multicollinearity (Wooldridge, 2016).
} 
SAENZ BARILLA New Approaches to U.S. Drug Policy

Table 3. Variance Inflation Factors (VIF) ${ }^{\mathrm{a}}$

\begin{tabular}{lccc}
\hline \multirow{2}{*}{\multicolumn{1}{c}{ Variables }} & Data Set 1 & Data Set 2 & Data Set 3 \\
\cline { 2 - 4 } & No. Obs. 360 & No. Obs. 60 & No. Obs. 340 \\
\hline $\begin{array}{l}\text { Log(Prohibition) }- \text { U.S. Interdiction } \\
\text { Expenditure }\end{array}$ & 1.82 & --- & 1.95 \\
\hline $\begin{array}{l}\text { Log(Prohibition) }- \text { U.S. International } \\
\text { Expenditure }\end{array}$ & --- & 1.95 & 1.72 \\
\hline Control-of-Corruption Index & 4.04 & 1.74 & 9.21 \\
\hline Unemployment Rate & 3.39 & 6.42 & 3.81 \\
\hline Relative Minimum Wage & 3.04 & 3.67 & 2.65 \\
\hline Human Capital Index & 3.68 & 4.18 & 6.05 \\
\hline Openness & 1.45 & 6.62 & 1.98 \\
\hline Log(Distance) & --- & --- & 2.18 \\
\hline Economic Freedom & 2.74 & 3.36 & 2.54 \\
\hline Tariff Rate & 3.68 & --- & 3.92 \\
\hline Internet Access & 7.86 & --- & 8.11 \\
\hline Log(U.S. Cocaine Price) & 2.93 & 1.87 & 3.4 \\
\hline Big Country & 1.3 & --- & 1.47 \\
\hline
\end{tabular}

a ---: not applicable (variable not used in the estimation). Multiple Imputation analyses used in the estimation of Model 1 (equation 1 for $i=1$; seizures) and Model 2 (real GDP growth and political stability) were the same Multiple Imputation analyses used in the VIF estimation for Data Set 1 and Data Set 3, respectively. The MLMV analysis was used to estimate the VIF for Data Set 2.

coca eradication. Data Set 3 includes data for the Latin American countries to assess the impact of U.S. drug prohibition policy in the region. Results from Table 3 confirmed multicollinearity is not a potential problem since the values for the VIFs are below $10 .^{30}$

Three steps were used in the estimation of the $i^{t h}$ illicit drug supply indicators (i.e. seizures, cultivation, potential production, and eradication) from equation (1), and the impact indicators (i.e. real GDP growth and political stability) from equations (2) and (3). First, the U.S. drug prohibition variable was regressed on the instrumental variable, the Ownership, Location, and Internalization variables, the demand proxy, the Big Country dummy variable, and the average

\footnotetext{
${ }^{30}$ Wooldridge (2016) states that choosing an arbitrary value for the VIF to conclude that multicollinearity is a problem is difficult. However, Wooldridge (2016) points to choosing a VIF greater than 10 to establish multicollinearity is a problem. Wooldridge (2016) argues that a VIF greater than 10 is equivalent to an R-squared from regressing the explanatory variable on all other independent variables of above 0.9 .
} 
of time-varying explanatory variables. Second, we obtain the estimated residuals from the prohibition regression in step one and included them as a covariate in the estimation of the illicit drug supply and impact indicators. Third, we regress each $i^{\text {th }}$ illicit drug supply indicator on the estimated residuals obtained in step two, the prohibition variable, and $\mathrm{XY} .{ }^{31} \mathrm{We}$ regress each $i^{t h}$ illicit drug supply indicator including one interaction effect one at a time. For the estimation of the impact indicators, the independent variables used in the system of equations (2) and (3) were the estimated residuals obtained in step two, the prohibition variable, and XY. If the estimated residuals were insignificant, they were dropped, and the equation was reestimated using the remaining variables.

\subsection{Missing at Random (MAR) Assumption}

For the MLMV and the Multiple Imputation analysis to minimize bias and obtain more efficient estimators, missing values have to be Missing at Random (MAR) (Newman, 2014). According to Allison (2010), data for a variable is MAR if the missingness of the variable depends on observed data, and not on the measures of the variable itself after controlling for the observed data. There is no available test to assess if the data is MAR, but we can diagnose MAR by looking at the correlation between missingness and observed data, and by estimating the probability of missingness as a function of the observed data.

Table 4 presents the percentage of missing observations in each of the data sets used in the estimations. Based on the percentages of missing observations, we analyze the MAR assumption for those variables where the percentage of missing observations is greater than 5 percent. ${ }^{32} \mathrm{~A}$ missingness-dummy variable was created for each variable with more than 5 percent of missing observations. The missingness-dummy variable takes a value of 1 if the variable has a missing observation and zero if otherwise. These dummy variables were used to estimate the pairwise correlations between missing data and the observed variables ${ }^{33}$ (Table 5), and to estimate the probability of missingness as a function of the observed data (Table 6).

\footnotetext{
${ }^{31} \mathrm{XY}$ stands for the Ownership, Location, and Internalization variables, demand proxy, Big Country dummy, and the average of time-varying explanatory variables. The following variables were excluded because of multicollinearity issues: the distance variable was excluded from the estimation of seizures, cultivation, potential production, and eradication; the tariff rate, internet access, and the Big Country dummy were excluded from the estimation of cultivation, potential production, and eradication.

${ }^{32}$ Variables with less than 5 percent missing data only represent one missing observation in each data set and are not expected to influence the consistency or efficiency of the estimator.

${ }^{33}$ Observed variables are understood to be those with no missing observations or less than 5 percent of missing data.
} 
SAENZ BARILLA New Approaches to U.S. Drug Policy

Table 4. Variables with Missing Data (Percentage of Missing Observations) ${ }^{\text {a }}$

\begin{tabular}{|c|c|c|c|}
\hline Variables & $\begin{array}{c}\text { Data Set 1: } \\
\text { Cocaine-Coca } \\
\text { Seizures } \\
\text { Estimation }\end{array}$ & $\begin{array}{c}\text { Data Set } 2 \\
\text { Cocaine-Coca } \\
\text { Producers } \\
\text { Estimation }\end{array}$ & $\begin{array}{c}\text { Data Set } 3 \\
\text { Latin American } \\
\text { Countries } \\
\text { Estimation }\end{array}$ \\
\hline & No. Obs. 360 & No. Obs. 60 & No. Obs. 340 \\
\hline Political Stability & --- & --- & 15 \\
\hline Cocaine-Coca Seizures & 0.28 & --- & --- \\
\hline Control-of-Corruption & 15 & 15 & 15 \\
\hline Relative Minimum Wage & 6.11 & 1.67 & 6.47 \\
\hline Openness & 0.28 & 0 & 0.29 \\
\hline Tariff Rate & 7.22 & --- & 7.65 \\
\hline
\end{tabular}

For the data used in the estimation of cocaine-coca seizures (i.e. Data Set 1), Table 5 indicates the missingness in the control-of-corruption index, relative minimum wage, and tariff rate variables are significantly associated (i.e. correlated) with observed data. Estimation of the probability of missingness in Table 6 confirms that the missingness depends on the observed data itself. For example, missingness in the control-of-corruption index can be predicted by the observed values of cocaine-coca seizure data, human capital index, economic freedom, openness, and internet access.

Similarly, for the data used in the estimation of coca cultivation, potential cocaine production, and coca eradication (i.e. Data Set 2), Table 5 indicates that missingness in the control-of-corruption index is significantly correlated with the observed data. Estimation of the missingness probability in the control-of-corruption index in Table 6 indicates that missingness depends on the observed values of U.S. international expenditures, unemployment rate, relative minimum wage, and economic freedom.

Finally, for the data set used in the estimation of the impact of U.S. drug prohibition policy in Latin American countries (i.e. Data Set 3), the pairwise correlation (Table 5) estimations indicate that missingness is significantly correlated with the observed data. A further assessment of the dependence of missingness on observed data can be predicted by the probability estimations of missingness as shown in Table 6. For example, missingness in the political stability variable and the tariff rate depend on the observed prohibition values as measured by U.S. international expenditures. 
Table 5. Pairwise Correlation between Variables with Complete Data and Variables with Missing Data ${ }^{\text {a }}$

\begin{tabular}{|c|c|c|c|c|c|c|c|c|c|}
\hline \multirow[b]{2}{*}{$\begin{array}{c}\text { Variables -Complete } \\
\text { Data }\end{array}$} & \multirow[b]{2}{*}{ 尊 } & \multicolumn{3}{|c|}{$\begin{array}{c}\text { Data Set } 1 \\
\text { Cocaine-Coca Seizure Estimation }\end{array}$} & \multirow{2}{*}{$\begin{array}{c}\text { Data Set } 2 \\
\text { Cocaine-Coca } \\
\text { Producers } \\
\text { Estimation } \\
\\
\\
\text { Control-of- } \\
\text { Corruption }\end{array}$} & \multicolumn{4}{|c|}{$\begin{array}{c}\text { Data Set } 3 \\
\text { Latin American Countries Estimation }\end{array}$} \\
\hline & & $\begin{array}{l}\text { Control-of- } \\
\text { Corruption }\end{array}$ & $\begin{array}{l}\text { Relative } \\
\text { Minimum } \\
\text { Wage }\end{array}$ & $\begin{array}{l}\text { Tariff } \\
\text { Rate }\end{array}$ & & $\begin{array}{l}\text { Political } \\
\text { Stability }\end{array}$ & $\begin{array}{l}\text { Control-of- } \\
\text { Corruption }\end{array}$ & $\begin{array}{l}\text { Relative } \\
\text { Minimum } \\
\text { Wage }\end{array}$ & $\begin{array}{l}\text { Tariff } \\
\text { Rate }\end{array}$ \\
\hline Cocaine-Coca Seizures & & $-0.12 * *$ & -0.084 & -0.02 & --- & --- & --- & --- & --- \\
\hline Coca Cultivation & & --- & --- & --- & 0.016 & --- & --- & --- & --- \\
\hline $\begin{array}{l}\text { Potential Cocaine } \\
\text { Production }\end{array}$ & & --- & --- & --- & 0.04 & --- & --- & --- & --- \\
\hline Coca Eradication & & --- & --- & --- & -0.13 & --- & --- & --- & --- \\
\hline Real GDP Growth & & --- & --- & --- & --- & $-0.16^{* * *}$ & $-0.16 * * *$ & -0.082 & 0.019 \\
\hline $\begin{array}{l}\text { U.S. Interdiction } \\
\text { Expenditure }\end{array}$ & & $-0.31 * * *$ & $-0.11 * *$ & $-0.27 * * *$ & --- & $-0.31 * * *$ & $-0.31 * * *$ & $-0.11 * *$ & $-0.28 * * *$ \\
\hline $\begin{array}{l}\text { U.S. International } \\
\text { Expenditure }\end{array}$ & & --- & --- & --- & $-0.47 * * *$ & $-0.47 * * *$ & $-0.47 * * *$ & -0.088 & $-0.34 * * *$ \\
\hline Unemployment Rate & & $0.13 * *$ & -0.051 & 0.0084 & 0.14 & $0.14 * * *$ & $0.14 * * *$ & -0.058 & 0.0013 \\
\hline Relative Minimum Wage & & --- & --- & --- & -0.2 & --- & --- & --- & --- \\
\hline Human Capital Index & & $-0.13 * *$ & -0.0091 & $-0.13 * *$ & $-0.28 * *$ & $-0.17 * * *$ & $-0.17 * * *$ & 0.041 & $-0.12 * *$ \\
\hline Openness & & -0.083 & 0.055 & $0.11 * *$ & $-0.27 * *$ & -0.087 & -0.087 & 0.039 & $0.1^{*}$ \\
\hline Distance & & --- & --- & --- & --- & -0.000000061 & -0.000000061 & -0.035 & $-0.12 * *$ \\
\hline Economic Freedom & & $0.11 * *$ & -0.051 & 0.027 & $0.25 *$ & $0.13^{* *}$ & $0.13 * *$ & -0.028 & 0.06 \\
\hline Internet Access & & $-0.34 * * *$ & $0.11 * *$ & $-0.13 * *$ & --- & $-0.37 * * *$ & $-0.37 * * *$ & $0.16^{* * *}$ & $-0.12 * *$ \\
\hline U.S. Cocaine Price & & $-0.27 * * *$ & $0.26 * * *$ & -0.068 & $-0.27 * *$ & $-0.27 * * *$ & $-0.27 * * *$ & $0.27 * * *$ & -0.07 \\
\hline
\end{tabular}

a $* * *, * * *$ indicates significant effects at the $1 \%, 5 \%$, and $10 \%$ significance level, respectively. ---: not applicable (variable not used in the estimation). We investigate the correlation between variables with no missing data or with less than 5 percent of missing data, and variables with more than 5 percent missing data. A dummy variable was constructed for each variable with more than 5 percent missing data to estimate the pairwise correlation 
SAENZ BARILLA New Approaches to U.S. Drug Policy

Table 6. Logistic Regression (Odds Ratio) for Missing Data - Data Set 1 and Data Set $2^{\text {a }}$

\begin{tabular}{|c|c|c|c|c|c|c|}
\hline & \multicolumn{3}{|c|}{$\begin{array}{c}\text { Data Set } 1 \\
\text { Used in Estimation of: Seizures }\end{array}$} & \multicolumn{3}{|c|}{$\begin{array}{l}\text { Data Set } 2 \\
\text { Used in Estimation of: Cultivation, } \\
\text { Potential Cocaine Production, and } \\
\text { Eradication }\end{array}$} \\
\hline & $\begin{array}{l}\text { Control-of- } \\
\text { Corruption }\end{array}$ & $\begin{array}{l}\text { Relative } \\
\text { Minimum } \\
\text { Wage }\end{array}$ & Tariff Rate & $\begin{array}{l}\text { Control- } \\
\text { of- } \\
\text { Corruption }\end{array}$ & $\begin{array}{l}\text { Control- } \\
\text { of- } \\
\text { Corruption }\end{array}$ & $\begin{array}{l}\text { Control- } \\
\text { of- } \\
\text { Corruption }\end{array}$ \\
\hline $\begin{array}{l}\text { Cocaine-Coca } \\
\text { Seizures }\end{array}$ & $\begin{array}{c}0.999 * * \\
(0.0000012)\end{array}$ & $\begin{array}{c}0.999 * * \\
(0.000014)\end{array}$ & $\begin{array}{c}1 \\
(0.00000078)\end{array}$ & --- & --- & --- \\
\hline Coca Cultivation & --- & --- & --- & $\begin{array}{c}1 \\
(0.000024)\end{array}$ & --- & --- \\
\hline $\begin{array}{l}\text { Potential Cocaine } \\
\text { Production }\end{array}$ & --- & --- & --- & --- & $\begin{array}{c}1.003 \\
(0.0051)\end{array}$ & --- \\
\hline Coca Eradication & --- & --- & --- & --- & --- & $\begin{array}{c}1 \\
(0.00002)\end{array}$ \\
\hline $\begin{array}{l}\text { U.S. Interdiction } \\
\text { Expenditure }\end{array}$ & $\begin{array}{c}1 \\
(0.00039)\end{array}$ & $\begin{array}{l}0.998 * * * \\
(0.00057)\end{array}$ & $\begin{array}{l}0.998 * * * \\
(0.00047)\end{array}$ & --- & --- & --- \\
\hline $\begin{array}{l}\text { U.S. International } \\
\text { Expenditure }\end{array}$ & --- & --- & --- & $\begin{array}{c}0.998 * * \\
(0.00099)\end{array}$ & $\begin{array}{l}0.998 * \\
(0.001)\end{array}$ & $\begin{array}{c}0.998 * \\
(0.0011)\end{array}$ \\
\hline Unemployment Rate & $\begin{array}{c}1.009 \\
(0.048)\end{array}$ & $\begin{array}{c}1.085 \\
(0.095)\end{array}$ & $\begin{array}{c}0.996 \\
(0.062)\end{array}$ & $\begin{array}{c}1.587 * * \\
(0.35)\end{array}$ & $\begin{array}{l}1.479^{*} \\
(0.33)\end{array}$ & $\begin{array}{c}1.621^{* *} \\
(0.34)\end{array}$ \\
\hline $\begin{array}{l}\text { Relative Minimum } \\
\text { Wage }\end{array}$ & --- & --- & --- & $\begin{array}{c}0.587 * * \\
(0.13)\end{array}$ & $\begin{array}{c}0.572 * * \\
(0.15)\end{array}$ & $\begin{array}{l}0.58 * * \\
(0.14)\end{array}$ \\
\hline $\begin{array}{l}\text { Human Capital } \\
\text { Index }\end{array}$ & $\begin{array}{c}3.559 * * \\
(2.12)\end{array}$ & $\begin{array}{c}14.08 * * \\
(18.9)\end{array}$ & $\begin{array}{l}0.278 \\
(0.23)\end{array}$ & $\begin{array}{l}1.102 \\
(4.73)\end{array}$ & $\begin{array}{c}0.656 \\
(3.003)\end{array}$ & $\begin{array}{l}1.179 \\
(4.96)\end{array}$ \\
\hline Openness & $\begin{array}{l}0.986 * * \\
(0.0067)\end{array}$ & $\begin{array}{c}0.989 \\
(0.0091)\end{array}$ & $\begin{array}{l}1.017 * * * \\
(0.0056)\end{array}$ & $\begin{array}{c}0.86 \\
(0.12)\end{array}$ & $\begin{array}{l}0.842 \\
(0.13)\end{array}$ & $\begin{array}{l}0.857 \\
(0.11)\end{array}$ \\
\hline Economic Freedom & $\begin{array}{l}1.07 * * \\
(0.03)\end{array}$ & $\begin{array}{l}0.999 \\
(0.05)\end{array}$ & $\begin{array}{c}1.02 \\
(0.041)\end{array}$ & $\begin{array}{c}1.916^{*} \\
(0.7)\end{array}$ & $\begin{array}{l}2.006^{*} \\
(0.77)\end{array}$ & $\begin{array}{l}1.892 * \\
(0.65)\end{array}$ \\
\hline Internet Access & $\begin{array}{l}0.86 * * * \\
(0.042)\end{array}$ & $\begin{array}{c}0.908 * * * \\
(0.031)\end{array}$ & $\begin{array}{c}1.011 \\
(0.027)\end{array}$ & --- & --- & --- \\
\hline U.S. Cocaine Price & $\begin{array}{c}1.006 \\
(0.011)\end{array}$ & $\begin{array}{c}1.152 * * * \\
(0.029)\end{array}$ & $\begin{array}{c}1.01 \\
(0.017) \\
\end{array}$ & $\begin{array}{c}1.014 \\
(0.061)\end{array}$ & $\begin{array}{l}1.011 \\
(0.06)\end{array}$ & $\begin{array}{c}1.019 \\
(0.053)\end{array}$ \\
\hline
\end{tabular}

a $* * *, * *, *$ indicates significant effects at the $1 \%, 5 \%$, and $10 \%$ significance level, respectively. Odds ratios reported. Robust standard errors of coefficients in parenthesis. ---: not applicable (variable not used in the estimation). 
Review of Economic Analysis 12 (2020) 271-319

Table 6. Logistic Regression (Odds Ratio) for Missing Data (Continued) - Data Set $3^{\text {a }}$

\begin{tabular}{|c|c|c|c|c|c|c|c|c|}
\hline \multirow[b]{2}{*}{ Real GDP Growth } & \multicolumn{2}{|c|}{ Political Stability } & \multicolumn{2}{|c|}{$\begin{array}{l}\text { Control-of- } \\
\text { Corruption }\end{array}$} & \multicolumn{2}{|c|}{$\begin{array}{c}\text { Relative Minimum } \\
\text { Wage }\end{array}$} & \multicolumn{2}{|c|}{ Tariff Rate } \\
\hline & $\begin{array}{c}0.913 \\
(0.055)\end{array}$ & $\begin{array}{l}0.856 * * \\
(0.056)\end{array}$ & $\begin{array}{c}0.913 \\
(0.055)\end{array}$ & $\begin{array}{l}0.856 * * \\
(0.056)\end{array}$ & $\begin{array}{c}0.873 \\
(0.078)\end{array}$ & $\begin{array}{l}0.852 * \\
(0.072)\end{array}$ & $\begin{array}{l}1.064 \\
(0.073)\end{array}$ & $\begin{array}{l}1.039 \\
(0.082)\end{array}$ \\
\hline $\begin{array}{l}\text { U.S. Interdiction } \\
\text { Expenditure }\end{array}$ & $\begin{array}{c}1.001 \\
(0.00045)\end{array}$ & --- & $\begin{array}{c}1.001 \\
(0.00045)\end{array}$ & --- & $\begin{array}{l}0.998 * * * \\
(0.00049)\end{array}$ & --- & $\begin{array}{l}0.998 * * * \\
(0.00048)\end{array}$ & --- \\
\hline $\begin{array}{l}\text { U.S. International } \\
\text { Expenditure }\end{array}$ & -- & $\begin{array}{l}0.998 * * * \\
(0.00036)\end{array}$ & --- & $\begin{array}{l}0.998 * * * \\
(0.00036)\end{array}$ & -- & $\begin{array}{c}0.997 * \\
(0.0018)\end{array}$ & -- & $\begin{array}{l}0.996 * * * \\
(0.00095)\end{array}$ \\
\hline $\begin{array}{l}\text { Unemployment } \\
\text { Rate }\end{array}$ & $\begin{array}{l}1.019 \\
(0.05)\end{array}$ & $\begin{array}{c}0.995 \\
(0.053)\end{array}$ & $\begin{array}{l}1.019 \\
(0.05)\end{array}$ & $\begin{array}{c}0.995 \\
(0.053)\end{array}$ & $\begin{array}{c}1.034 \\
(0.061)\end{array}$ & $\begin{array}{c}1.024 \\
(0.063)\end{array}$ & $\begin{array}{c}1.005 \\
(0.062)\end{array}$ & $\begin{array}{c}0.997 \\
(0.073)\end{array}$ \\
\hline $\begin{array}{l}\text { Human Capital } \\
\text { Index }\end{array}$ & $\begin{array}{l}3.602 \\
(2.88)\end{array}$ & $\begin{array}{l}3.253 \\
(2.83)\end{array}$ & $\begin{array}{l}3.602 \\
(2.88)\end{array}$ & $\begin{array}{l}3.253 \\
(2.83)\end{array}$ & $\begin{array}{l}3.191 \\
(4.24)\end{array}$ & $\begin{array}{l}1.874 \\
(2.37)\end{array}$ & $\begin{array}{l}0.609 \\
(0.54)\end{array}$ & $\begin{array}{c}0.539 \\
(0.5)\end{array}$ \\
\hline Openness & $\begin{array}{c}0.993 \\
(0.0067)\end{array}$ & $\begin{array}{c}0.994 \\
(0.0073)\end{array}$ & $\begin{array}{c}0.993 \\
(0.0067)\end{array}$ & $\begin{array}{c}0.994 \\
(0.0073)\end{array}$ & $\begin{array}{c}1.004 \\
(0.0084)\end{array}$ & $\begin{array}{c}1.005 \\
(0.0084)\end{array}$ & $\begin{array}{c}1.009 \\
(0.0062)\end{array}$ & $\begin{array}{c}1.013 * \\
(0.0073)\end{array}$ \\
\hline Distance & $\begin{array}{c}0.999 \\
(0.00021)\end{array}$ & $\begin{array}{c}0.999 \\
(0.00022)\end{array}$ & $\begin{array}{c}0.999 \\
(0.00021)\end{array}$ & $\begin{array}{c}0.999 \\
(0.00022)\end{array}$ & $\begin{array}{c}1 \\
(0.00027)\end{array}$ & $\begin{array}{c}0.999 \\
(0.00023)\end{array}$ & $\begin{array}{c}0.999 * \\
(0.00021)\end{array}$ & $\begin{array}{c}0.999 * * \\
(0.00021)\end{array}$ \\
\hline Economic Freedom & $\begin{array}{c}1.057 * \\
(0.033)\end{array}$ & $\begin{array}{c}1.059 * \\
(0.036)\end{array}$ & $\begin{array}{c}1.057 * \\
(0.033) \\
\end{array}$ & $\begin{array}{l}1.059^{*} \\
(0.036)\end{array}$ & $\begin{array}{c}1.029 \\
(0.041)\end{array}$ & $\begin{array}{c}1.029 \\
(0.028)\end{array}$ & $\begin{array}{c}1.031 \\
(0.042)\end{array}$ & $\begin{array}{c}1.03 \\
(0.041)\end{array}$ \\
\hline Internet Access & $\begin{array}{c}0.739 * * * \\
(0.066)\end{array}$ & $\begin{array}{c}0.81 * * * \\
(0.047)\end{array}$ & $\begin{array}{c}0.739 * * * \\
(0.066)\end{array}$ & $\begin{array}{c}0.81 * * * \\
(0.047)\end{array}$ & $\begin{array}{c}0.925 * * \\
(0.031)\end{array}$ & $\begin{array}{c}0.955 \\
(0.029)\end{array}$ & $\begin{array}{c}1.009 \\
(0.029)\end{array}$ & $\begin{array}{c}1.045 \\
(0.033)\end{array}$ \\
\hline U.S. Cocaine Price & $\begin{array}{l}1.025^{*} \\
(0.015)\end{array}$ & $\begin{array}{c}1.054 * * * \\
(0.016)\end{array}$ & $\begin{array}{l}1.025^{*} \\
(0.015)\end{array}$ & $\begin{array}{c}1.054 * * * \\
(0.016)\end{array}$ & $\begin{array}{c}1.128 * * * \\
(0.026)\end{array}$ & $\begin{array}{c}1.112 * * * \\
(0.031)\end{array}$ & $\begin{array}{c}1.007 \\
(0.019)\end{array}$ & $\begin{array}{l}1.015 \\
(0.02)\end{array}$ \\
\hline
\end{tabular}

a $* * *, * *, *$ indicates significant effects at the $1 \%, 5 \%$, and $10 \%$ significance level, respectively. Odds ratios reported. Robust standard errors of coefficients in parenthesis. ---: not applicable (variable not used in the estimation). 


\section{Results}

An instrumental variable (IV) was used to identify the impact of U.S. drug prohibition policy on the illicit drug supply indicators, real GDP growth, and political stability. For the instrument to be valid after controlling for other relevant factors, the IV needs to predict changes in the size of U.S. drug prohibition policy (i.e. relevance assumption), and be unrelated to changes in the illicit drug supply and impact indicators (i.e. exclusion assumption) while being uncorrelated to the error terms in equations 1,2 , and 3 (i.e. exogeneity assumption). ${ }^{34}$

We explore the relevance of the IV to predict U.S. drug prohibition policy by referring to the estimation of factors affecting U.S. interdiction and international expenditure in Table 7. Data Set 1 (i.e. column 1 in Table 7 using data for all countries with seizure values) is used to assess the factors affecting prohibition when U.S. drug prohibition policy is measured as U.S. interdiction expenditure. Data Set 3 (i.e. column 4 in Table 7 using data for Latin American countries) is used to assess factors affecting prohibition when U.S. drug prohibition policy is measured as U.S. international expenditure. Results indicate that the IV significantly impacts U.S. drug prohibition policy after controlling for all other relevant factors making the U.S. political administration dummy a relevant instrument.

The IV also needs to have no direct effect on the illicit supply indicators, real GDP growth, and political stability (i.e. exclusion restriction). Table 8 presents the estimation of the illicit supply indicators, real GDP growth, and political stability. As shown in Table 8, the IV does not significantly impact seizures, cultivation, potential cocaine production, real GDP growth, and political stability, therefore, the U.S. political administration dummy satisfies the exclusion restriction for all dependent variables, except eradication. ${ }^{35}$ However, there is no reason to believe that the election of a Democratic or Republican administration in the U.S. has a direct impact on eradication, except through the effectiveness of the U.S. drug prohibition policy. The average of coca eradication (hectares) during a Democratic administration was not statistically different than the average of coca eradication during a Republican administration. ${ }^{36}$

In addition, the exogeneity of the IV might be called into question if the factors influencing the election of a Democratic or Republican administration also affect the dependent variables (i.e. illicit supply indicators, real GDP growth, and political stability), and are not accounted

\footnotetext{
${ }^{34}$ Wooldridge (2016) defines the exogeneity and exclusion assumptions as the instrument exogeneity assumption. In here, we are more specific by defining exogeneity in terms of the correlation of the instrumental variable with the error term, and the exclusion restriction as the instrumental variable not having a partial effect on the dependent variable after controlling for other relevant variables.

${ }^{35}$ The IV significantly impacts eradication at the 5 percent significance level.

${ }^{36}$ A t-test on the equality of means was not statistically significant at the standard significance levels.
} 
Review of Economic Analysis 12 (2020) 271-319

Table 7. Factors Affecting Prohibition (Lognormal Estimates) ${ }^{\mathrm{a} ; \mathrm{b}}$

\begin{tabular}{|c|c|c|c|c|}
\hline $\begin{array}{l}\text { Dependent } \\
\text { Variable }\end{array}$ & $\begin{array}{l}\text { Log(U.S. Interdiction } \\
\text { Expenditure) }\end{array}$ & $\begin{array}{c}\log (\text { U.S. International } \\
\text { Expenditure })\end{array}$ & $\begin{array}{c}\text { Log(U.S. } \\
\text { Interdiction } \\
\text { Expenditure) }\end{array}$ & $\begin{array}{c}\text { Log(U.S. } \\
\text { International } \\
\text { Expenditure) }\end{array}$ \\
\hline & $\begin{array}{l}\text { Data Set } 1 \text { Cocaine- } \\
\text { Coca Seizures }\end{array}$ & $\begin{array}{c}\text { Data Set } 2 \\
\text { Cocaine-Coca Producers }\end{array}$ & \multicolumn{2}{|c|}{$\begin{array}{c}\text { Data Set } 3 \\
\text { Latin American Countries }\end{array}$} \\
\hline & No. Obs. 360 & No. Obs. 60 & \multicolumn{2}{|c|}{ No. Obs. 340} \\
\hline Independent Vars. & Coefficient & Coefficient & Coefficient & Coefficient \\
\hline IV & $\begin{array}{l}0.11^{* * *} \\
(0.026)\end{array}$ & $\begin{array}{c}0.25 \\
(0.16)\end{array}$ & $\begin{array}{c}0.084 * * * \\
(0.026)\end{array}$ & $\begin{array}{l}0.27 * * * \\
(0.062)\end{array}$ \\
\hline $\begin{array}{l}\text { Control-of- } \\
\text { Corruption Index }\end{array}$ & $\begin{array}{l}0.0046 \\
(0.027)\end{array}$ & $\begin{array}{c}0.48 \\
(0.38)\end{array}$ & $\begin{array}{l}0.101^{* *} \\
(0.046)\end{array}$ & $\begin{array}{c}0.21 * * \\
(0.1)\end{array}$ \\
\hline Unemployment Rate & $\begin{array}{l}-0.0019 \\
(0.005)\end{array}$ & $\begin{array}{c}0.071 * * * \\
(0.025)\end{array}$ & $\begin{array}{l}-0.0051 \\
(0.0054)\end{array}$ & $\begin{array}{l}0.0047 \\
(0.011)\end{array}$ \\
\hline $\begin{array}{l}\text { Relative Minimum } \\
\text { Wage }\end{array}$ & $\begin{array}{c}-0.0013 \\
(0.00092)\end{array}$ & $\begin{array}{c}-0.00088 \\
(0.021)\end{array}$ & $\begin{array}{c}0.0017 \\
(0.0018)\end{array}$ & $\begin{array}{l}0.0059 * * \\
(0.0029)\end{array}$ \\
\hline $\begin{array}{l}\text { Human Capital } \\
\text { Index }\end{array}$ & $\begin{array}{l}-0.0025 \\
(0.04)\end{array}$ & $\begin{array}{l}1.22 * * * \\
(0.39)\end{array}$ & $\begin{array}{c}0.13^{*} \\
(0.072)\end{array}$ & $\begin{array}{l}0.32 * * \\
(0.15)\end{array}$ \\
\hline Openness & $\begin{array}{l}0.00066^{*} \\
(0.00036)\end{array}$ & $\begin{array}{c}0.014 * \\
(0.0079)\end{array}$ & $\begin{array}{l}0.00013 \\
(0.00045)\end{array}$ & $\begin{array}{l}-0.00058 \\
(0.00094)\end{array}$ \\
\hline Log(Distance) & --- & --- & $\begin{array}{l}-0.053 \\
(0.035)\end{array}$ & $\begin{array}{c}-0.13 \\
(0.079)\end{array}$ \\
\hline Economic Freedom & $\begin{array}{l}-0.0028 \\
(0.002)\end{array}$ & $\begin{array}{c}0.011 \\
(0.012)\end{array}$ & $\begin{array}{l}-0.0022 \\
(0.0019)\end{array}$ & $\begin{array}{l}-0.0011 \\
(0.004)\end{array}$ \\
\hline Tariff Rate & $\begin{array}{c}-0.035^{* * *} \\
(0.0047) \\
\end{array}$ & -- & $\begin{array}{l}-0.04 * * * \\
(0.0049)\end{array}$ & $\begin{array}{c}-0.069^{* * *} \\
(0.011)\end{array}$ \\
\hline Internet Access & $\begin{array}{l}0.0033 * * \\
(0.0016)\end{array}$ & --- & $\begin{array}{l}0.00033 \\
(0.0018)\end{array}$ & $\begin{array}{l}-0.0042 \\
(0.0032)\end{array}$ \\
\hline $\begin{array}{l}\text { Log(U.S. Price } \\
\text { Cocaine) }\end{array}$ & $\begin{array}{c}0.076 \\
(0.069)\end{array}$ & $\begin{array}{l}0.73 * * \\
(0.34)\end{array}$ & $\begin{array}{c}0.071 \\
(0.072)\end{array}$ & $\begin{array}{l}0.61 * * * \\
(0.15)\end{array}$ \\
\hline Big Country & $\begin{array}{c}0.015 \\
(0.027)\end{array}$ & -- & $\begin{array}{l}-0.0038 \\
(0.029)\end{array}$ & $\begin{array}{c}-0.028 \\
(0.063)\end{array}$ \\
\hline Observations & 360 & 60 & 340 & 340 \\
\hline R-Squared & 0.47 & 0.52 & 0.49 & 0.44 \\
\hline
\end{tabular}

a $* * *, * *, *$ indicates significant effects at the $1 \%, 5 \%$, and $10 \%$ significance level, respectively. Robust standard errors in parenthesis. ---: not applicable (variable not used in the estimation due to high correlation with other regressors). Data Set 1 includes the Latin American countries and the U.S., Data Set 2 includes main cocaine-coca producers (i.e. Colombia, Peru, and Bolivia), and Data Set 3 includes Latin American countries as listed in the data section.

${ }^{\mathbf{b}}$ Implementation of the CRE approach involves the control of covariates that statistically change over time (results not reported). Mean of variables that statistically change over time and have a correlation higher than 0.8 with other covariates used in the regression are excluded to avoid multicollinearity. Therefore, for each data set the following variables are included: Data Set 1 - mean of the unemployment rate and tariff rate; Data Set 2 - no additional means are included; Data Set 3 - mean of the unemployment rate, tariff rate, and internet access. 
SAENZ BARILLA New Approaches to U.S. Drug Policy

Table 8: Testing Exclusion Restriction of IV ${ }^{\text {a }}$

\begin{tabular}{|c|c|c|c|c|c|c|}
\hline & $\begin{array}{c}\text { Log(Cocaine- } \\
\text { Coca } \\
\text { Seizures })\end{array}$ & $\begin{array}{l}\log (\text { Coca } \\
\text { Cultivation) }\end{array}$ & $\begin{array}{l}\text { Log }(\text { Potential } \\
\text { Cocaine } \\
\text { Production })\end{array}$ & $\begin{array}{c}\log (\text { Coca } \\
\text { Eradication })\end{array}$ & $\begin{array}{l}\text { Real GDP } \\
\text { Growth }\end{array}$ & $\begin{array}{l}\text { Political } \\
\text { Stability }\end{array}$ \\
\hline & $\begin{array}{c}\text { Data Set } 1 \\
\text { No. Obs. } 360\end{array}$ & \multicolumn{3}{|c|}{ Data Set 2 - No. Obs. 60} & \multicolumn{2}{|c|}{$\begin{array}{l}\text { Data Set } 3 \\
\text { No. Obs. } 340 \\
\end{array}$} \\
\hline \multicolumn{7}{|c|}{ Independent Variables } \\
\hline IV & $\begin{array}{l}0.046 \\
(0.25)\end{array}$ & $\begin{array}{l}-0.084 \\
(0.091)\end{array}$ & $\begin{array}{l}-0.059 \\
(0.13)\end{array}$ & $\begin{array}{l}0.5^{* *} \\
(0.22)\end{array}$ & $\begin{array}{l}-0.37 \\
(0.47)\end{array}$ & $\begin{array}{l}-0.11 \\
(0.068)\end{array}$ \\
\hline $\begin{array}{l}\text { Control-of- } \\
\text { Corruption Index }\end{array}$ & $\begin{array}{l}-0.32 \\
(0.26)\end{array}$ & $\begin{array}{l}0.43^{*} \\
(0.23)\end{array}$ & $\begin{array}{c}0.27 \\
(0.29)\end{array}$ & $\begin{array}{l}-0.7 \\
(0.68)\end{array}$ & $\begin{array}{l}1.05 \\
(0.88)\end{array}$ & $\begin{array}{c}0.17^{*} \\
(0.092)\end{array}$ \\
\hline $\begin{array}{l}\text { Unemployment } \\
\text { Rate }\end{array}$ & $\begin{array}{c}-0.02 \\
(0.043)\end{array}$ & $\begin{array}{l}-0.016 \\
(0.015)\end{array}$ & $\begin{array}{c}0.019 \\
(0.019)\end{array}$ & $\begin{array}{l}-0.029 \\
(0.036)\end{array}$ & $\begin{array}{c}-0.38 * * * \\
(0.11)\end{array}$ & $\begin{array}{l}-0.022 * * \\
(0.0098)\end{array}$ \\
\hline $\begin{array}{l}\text { Relative } \\
\text { Minimum Wage }\end{array}$ & $\begin{array}{l}0.026 * * * \\
(0.0071)\end{array}$ & $\begin{array}{c}0.057 * * * \\
(0.013)\end{array}$ & $\begin{array}{c}0.045 * * * \\
(0.013)\end{array}$ & $\begin{array}{l}0.13^{* * *} \\
(0.031)\end{array}$ & $\begin{array}{l}-0.0093 \\
(0.028)\end{array}$ & $\begin{array}{c}-0.016 * * * \\
(0.0032)\end{array}$ \\
\hline $\begin{array}{l}\text { Human Capital } \\
\text { Index }\end{array}$ & $\begin{array}{l}1.91^{* * *} \\
(0.34)\end{array}$ & $\begin{array}{c}-1.90 * * * \\
(0.29)\end{array}$ & $\begin{array}{l}-0.29 \\
(0.33)\end{array}$ & $\begin{array}{c}-4.03 * * * \\
(0.69)\end{array}$ & $\begin{array}{c}0.59 \\
(1.04)\end{array}$ & $\begin{array}{l}-0.048 \\
(0.13)\end{array}$ \\
\hline Openness & $\begin{array}{l}-0.0027 \\
(0.0029)\end{array}$ & $\begin{array}{l}-0.0049 \\
(0.005)\end{array}$ & $\begin{array}{l}-0.0022 \\
(0.0060)\end{array}$ & $\begin{array}{l}0.0037 \\
(0.014)\end{array}$ & $\begin{array}{l}0.032 * * * \\
(0.0067)\end{array}$ & $\begin{array}{l}0.0048 * * * \\
(0.00079)\end{array}$ \\
\hline Log(Distance) & --- & --- & --- & --- & $\begin{array}{l}-0.12 \\
(0.71)\end{array}$ & $\begin{array}{l}0.49 * * * \\
(0.074)\end{array}$ \\
\hline $\begin{array}{l}\text { Economic } \\
\text { Freedom }\end{array}$ & $\begin{array}{l}-0.033^{*} \\
(0.017)\end{array}$ & $\begin{array}{l}-0.017 * * \\
(0.0077)\end{array}$ & $\begin{array}{c}-0.015 \\
(0.0095)\end{array}$ & $\begin{array}{l}-0.016 \\
(0.024)\end{array}$ & $\begin{array}{c}-0.073^{* *} \\
(0.032)\end{array}$ & $\begin{array}{c}-0.011 * * * \\
(0.0035)\end{array}$ \\
\hline Tariff Rate & $\begin{array}{l}-0.047 \\
(0.05)\end{array}$ & --- & --- & --- & $\begin{array}{l}-0.13 \\
(0.088)\end{array}$ & $\begin{array}{l}0.0046 \\
(0.01)\end{array}$ \\
\hline Internet Access & $\begin{array}{l}0.0024 \\
(0.01)\end{array}$ & --- & --- & --- & $\begin{array}{c}0.028 \\
(0.025)\end{array}$ & $\begin{array}{c}0.0074^{* *} \\
(0.0032)\end{array}$ \\
\hline $\begin{array}{l}\text { Log(U.S. } \\
\text { Cocaine Price })\end{array}$ & $\begin{array}{l}-0.069 \\
(0.58)\end{array}$ & $\begin{array}{l}0.39^{*} \\
(0.21)\end{array}$ & $\begin{array}{l}-0.049 \\
(0.28)\end{array}$ & $\begin{array}{c}1.37 * * * \\
(0.5)\end{array}$ & $\begin{array}{c}-5.32 * * * \\
(1.01)\end{array}$ & $\begin{array}{l}-0.24 \\
(0.15)\end{array}$ \\
\hline Big Country & $\begin{array}{c}3.89 * * * \\
(0.24)\end{array}$ & --- & --- & --- & $\begin{array}{c}1.43 * * * \\
(0.44)\end{array}$ & $\begin{array}{c}-0.73 * * * \\
(0.06)\end{array}$ \\
\hline R-Squared & 0.62 & 0.89 & 0.63 & 0.83 & & \\
\hline
\end{tabular}

a $* * *, * *, *$ indicates significant effects at the $1 \%, 5 \%$, and $10 \%$ significance level, respectively. Robust standard errors in parenthesis. ---: not applicable (variable not used in the estimation). The MLMV approach is used in the estimation of coca cultivation, potential cocaine production, and coca eradication. For the MLMV estimation, we fail to reject the Jarque-Bera test of normality at all standard significance levels for the coca eradication and potential cocaine production estimations. We fail to reject the Jarque-Bera test of normality at the 1 percent significance level for the coca eradication estimation. Multiple Imputation analysis was used in the estimation of cocaine-coca seizures, real GDP growth, and political stability. 
for in the estimation. Historical political attitudes in the United States have been shaped by family attitudes, gender, religion, race, ethnicity, and geographical region in the U.S. (Independence Hall Association, 2019). Those factors affecting political attitudes are different from those we theorized, in the context of Transnational Criminal Enterprises, affect illicit supply indicators. In addition, factors affecting historical political attitudes in the U.S. are different from the factors affecting economic growth and political stability in Latin American countries.

Table 7 also reveals the factors that significantly affect U.S. prohibition in Latin America (i.e. columns 3 and 4). Results indicate Latin American countries that have less corrupted governments, a more educated population, and fewer restrictions on international trade are linked to greater U.S. expenditures for illicit drug interdiction and international drug control efforts. U.S. drug prohibition policy in Latin American countries appears to be driven by the government's ability to manage those resources allocated for illicit drug supply control and the restrictions imposed to international trade. In addition, higher retail prices for cocaine in the U.S. are associated with greater U.S. expenditures on international drug control efforts.

Tables 9-14 show results for the illicit drug supply indicators estimation. For brevity, Table 13 reports only the significant estimates from the regression run for each $i^{t h}$ illicit drug supply indicator before including any interaction of U.S. drug prohibition policy with the Ownership, Location, and Internalization variables. Table 14 reports the estimates for significant joint hypothesis of the prohibition and its corresponding interaction effect.

Table 13 results indicate that U.S. drug prohibition policy significantly impacts cocainecoca supply at the source but not in transit. Table 13 reveals that a 10 percent increase in U.S. drug prohibition policy spending, measured as international expenditure, reduces potential cocaine production by 3.5 percent and increases on-site coca eradications by approximately 26 percent. Caulkins and Reuter (2010) report that significant cocaine-coca supply control efforts at the source country are viewed as inefficient, since the cost of cultivating and refining the drug is less than 1 percent of the U.S. cocaine retail price. However, Caulkins and Reuter (2010) point that illegality and enforcement can keep U.S. cocaine retail prices higher and availability to the consumer much lower as would be the case if there were no prohibition or enforcement.

Table 13 results are consistent with other authors' argument that U.S. drug prohibition policy has not significantly disrupted the cocaine-coca supply in transit. Seizures insignificantly affect the Transnational Criminal Enterprise financially because smuggling costs are a small percentage of the final U.S. cocaine retail price and because Transnational Criminal Enterprises change smuggling routes thereby hedging against the risk of seizures (Andreas, 2000; Caulkins and Reuter, 2010; Keck and Correa-Cabrera, 2015; Moore, 1990). Successful interdiction policies in one country have only displaced operations to other locations, without reducing the 
amount of drugs transacted. Mejia and Restrepo (2014) reveal that successful interdiction policies in Colombia in 2007, resulted with the displacement of cocaine-coca production and trafficking organizations. ${ }^{37}$ Similarly, Giommoni et al., (2017) found that greater seizures failed to prevent the formation of heroin trafficking flows in Europe.

Our results reveal that the Ownership variable, control-of-corruption index, significantly affects Transnational Criminal Enterprises when it comes to on-site cocaine-coca supply. Greater control-of-corruption is advantageous to Transnational Criminal Enterprises by significantly increasing coca cultivation, potential cocaine production, and reducing coca eradication. Further, our results support Mudambi and Paul's (2003) assertion that less corruption decreases production costs for Transnational Criminal Enterprises thereby facilitating their expansion. This study's results also point out that the monetary cost of bribes are higher than other monetary/non-monetary costs associated with the production of cocainecoca.

Location variables, such as the state of the labor market (i.e. unemployment rate and relative minimum wage), human capital levels, and openness, significantly affect Transnational Criminal Enterprises locational decisions in Latin America. As unemployment rates increase, Transnational Criminal Enterprises gain advantages due to increases in potential cocaine production and reductions in coca eradication. Unemployment rates have been found to have a positive association with the size of the shadow economy as economic downturns drive unemployed individuals into the shadow economy (Dell'Anno and Solomon, 2008). Transnational Criminal Enterprises benefit from individuals driven to the shadow economy due to lost employment. In the case of relative minimum wages, Transnational Criminal Enterprises gain advantages with higher local wages as those are associated with higher coca cultivation and potential cocaine production, but those advantages are diminished as higher local wages also increase the expected seizures and eradication efforts. According to Reuter (1992), crop eradication efforts increase the risks and costs to farmers which should be reflected on the income they receive in order for them to stay in the market. Thus, higher wages ${ }^{38}$ become an incentive for farmers to increase cocaine-coca production in order to cover the risks farmers face as result of prohibition. On the other hand, higher minimum wages have also been found to spur productivity and increase output (Booth and Frank, 1999). Results showed in Table 13 also indicate that reduced human capital increases coca cultivation. Reduced human capital levels lower the opportunity cost of crime (Lochner, 2004), and also provides a cheaper labor force. Greater globalization (i.e. greater openness) also benefits Transnational Criminal

\footnotetext{
${ }^{37}$ Coca cultivation was displaced to Peru and Bolivia, cocaine processing to Venezuela, and trafficking organizations to Mexico and Central America.

${ }^{38} \mathrm{We}$ assume illegal wages reflect changes in legal wages. If legal wages increase, illegal wages will also have to increase to induce farmers to engage in illegal drug production since those activities involve higher risk.
} 
Enterprises by reducing on-site eradications. The effect of openness on Transnational Criminal Enterprises does not support Enderwick (2009)'s discussion on how globalization generates income inequality and provides an opportunity for Translational Criminal Enterprises to target marginalized segments of the population, as globalization does not significantly impact on-site cocaine-coca production.

Table 13 also reveals that the Internalization variable, economic freedom, has a significant impact on the locational decisions of Transnational Criminal Enterprises. Greater economic freedom becomes disadvantageous to Transnational Criminal Enterprises by reducing coca cultivation. This result potentially signals changes in the producers' behavior by giving them incentives to engage in the legal economy. Our results support Muñoz-Mora et al. (2018) and Felbab-Brown (2014) discussion on the importance of property rights, and access to productive resources and markets in decreasing the size of illicit drug cultivation. Results also indicate that increased levels of economic freedom lead to less seizures and on-site eradications.

Table 14 reports interaction-effect estimates from the significant joint hypothesis, obtained from each $i^{\text {th }}$ illicit drug supply indicator regression. ${ }^{39}$ The interaction variables are used to assess whether prohibition gives Ownership, Location or Internalization advantages to Transnational Criminal Enterprises, while a reduction of on-site production and an increase in transport seizures implies effective U.S. drug prohibition policy. ${ }^{40}$

Results in Table 14 indicate that U.S. drug prohibition policy is more effective at reducing coca cultivation and potential cocaine production in main cocaine-coca producer countries with less corruption and higher human capital. However, the policy's effectiveness is limited by the impact that higher unemployment rates and higher local minimum wages have on on-site illicit drug production. Additionally, greater economic freedom and globalization strengthen the effect of U.S. drug prohibition policy on reducing potential cocaine production. In terms of eradication efforts, the lower the control-of-corruption index, human capital, economic freedom, and openness the more effective U.S. drug prohibition policy is at increasing on-site eradications. Furthermore, higher unemployment rates and local minimum wages, also make U.S. drug prohibition policy more effective by strengthening on-site eradication efforts.

Unfortunately, U.S. drug prohibition policy can potentially benefit Transnational Criminal Enterprises. Our results indicate that the tougher the U.S. drug prohibition policy is, the larger the effect unemployment and local minimum wages have on increasing cocaine-coca on-site

\footnotetext{
${ }^{39}$ Null hypothesis: the prohibition and interaction effect are jointly equal to zero. Each regression analysis includes one interaction effect at a time.

${ }^{40}$ Ownership, Location, or Internalization variables result in locational advantages to Transnational Criminal Enterprises if they reduce expected seizures and increase expected on-site production.
} 
SAENZ BARILLA New Approaches to U.S. Drug Policy

Table 9. Cocaine-Coca Seizures Estimation (Lognormal Estimates) ${ }^{a}$

\begin{tabular}{|c|c|c|c|c|c|}
\hline Independent Variables & Coeff. & Coeff. & Coeff. & Coeff. & Coeff. \\
\hline Log(Prohibition) & $\begin{array}{c}0.66 \\
(0.48)\end{array}$ & $\begin{array}{c}0.76 \\
(0.50)\end{array}$ & $\begin{array}{c}1.11 \\
(0.98)\end{array}$ & $\begin{array}{l}0.84 \\
(0.7)\end{array}$ & $\begin{array}{l}-0.26 \\
(1.81)\end{array}$ \\
\hline $\begin{array}{l}\text { Log(Prohibition) by } \\
\text { Control-of-Corruption } \\
\text { Index }\end{array}$ & & $\begin{array}{c}0.38 \\
(0.56)\end{array}$ & & & \\
\hline $\begin{array}{l}\text { Log(Prohibition) by } \\
\text { Unemployment Rate }\end{array}$ & & & $\begin{array}{l}-0.059 \\
(0.11) \\
\end{array}$ & & \\
\hline $\begin{array}{l}\text { Log(Prohibition) by } \\
\text { Relative Minimum Wage }\end{array}$ & & & & $\begin{array}{l}-0.0065 \\
(0.014)\end{array}$ & \\
\hline $\begin{array}{l}\text { Log(Prohibition) by } \\
\text { Human Capital Index }\end{array}$ & & & & & $\begin{array}{c}0.38 \\
(0.71)\end{array}$ \\
\hline $\begin{array}{l}\text { Control-of-Corruption } \\
\text { Index }\end{array}$ & $\begin{array}{l}-0.32 \\
(0.26)\end{array}$ & $\begin{array}{l}-3.33 \\
(4.43)\end{array}$ & $\begin{array}{l}-0.32 \\
(0.26)\end{array}$ & $\begin{array}{l}-0.34 \\
(0.26)\end{array}$ & $\begin{array}{l}-0.31 \\
(0.26)\end{array}$ \\
\hline Unemployment Rate & $\begin{array}{l}-0.019 \\
(0.043)\end{array}$ & $\begin{array}{l}-0.027 \\
(0.046)\end{array}$ & $\begin{array}{c}0.44 \\
(0.88)\end{array}$ & $\begin{array}{l}-0.016 \\
(0.044)\end{array}$ & $\begin{array}{l}-0.021 \\
(0.044)\end{array}$ \\
\hline Relative Minimum Wage & $\begin{array}{c}0.027 * * * \\
(0.0071)\end{array}$ & $\begin{array}{c}0.027 * * * \\
(0.0074)\end{array}$ & $\begin{array}{c}0.027 * * * \\
(0.0071)\end{array}$ & $\begin{array}{l}0.078 \\
(0.11) \\
\end{array}$ & $\begin{array}{r}0.027 * * * \\
(0.0074)\end{array}$ \\
\hline Human Capital Index & $\begin{array}{c}1.92 * * * \\
(0.34)\end{array}$ & $\begin{array}{c}1.99 * * * \\
(0.34)\end{array}$ & $\begin{array}{l}1.9 * * * \\
(0.33)\end{array}$ & $\begin{array}{l}1.9 * * * \\
(0.34)\end{array}$ & $\begin{array}{c}-1.1 \\
(5.65)\end{array}$ \\
\hline Openness & $\begin{array}{l}-0.0032 \\
(0.0029)\end{array}$ & $\begin{array}{l}-0.0034 \\
(0.0029)\end{array}$ & $\begin{array}{l}-0.0033 \\
(0.003)\end{array}$ & $\begin{array}{l}-0.0032 \\
(0.0029)\end{array}$ & $\begin{array}{l}-0.0033 \\
(0.0029)\end{array}$ \\
\hline Economic Freedom & $\begin{array}{l}-0.031 * \\
(0.017)\end{array}$ & $\begin{array}{c}-0.033^{* *} \\
(0.017)\end{array}$ & $\begin{array}{c}-0.031 * \\
(0.017)\end{array}$ & $\begin{array}{c}-0.03 * \\
(0.017)\end{array}$ & $\begin{array}{c}-0.031 * \\
(0.017)\end{array}$ \\
\hline Tariff Rate & $\begin{array}{l}-0.023 \\
(0.052)\end{array}$ & $\begin{array}{c}-0.027 \\
(0.052)\end{array}$ & $\begin{array}{c}-0.021 \\
(0.052)\end{array}$ & $\begin{array}{l}-0.018 \\
(0.057)\end{array}$ & $\begin{array}{l}-0.026 \\
(0.053)\end{array}$ \\
\hline Internet Access & $\begin{array}{c}-0.000015 \\
(0.01)\end{array}$ & $\begin{array}{l}-0.0043 \\
(0.012)\end{array}$ & $\begin{array}{c}0.00055 \\
(0.01)\end{array}$ & $\begin{array}{l}0.0015 \\
(0.012)\end{array}$ & $\begin{array}{l}-0.002 \\
(0.011)\end{array}$ \\
\hline Log(U.S. Cocaine Price) & $\begin{array}{c}-0.08 \\
(0.41)\end{array}$ & $\begin{array}{l}0.022 \\
(0.44) \\
\end{array}$ & $\begin{array}{c}-0.12 \\
(0.41)\end{array}$ & $\begin{array}{l}-0.12 \\
(0.43) \\
\end{array}$ & $\begin{array}{c}-0.028 \\
(0.43)\end{array}$ \\
\hline Big Country & $\begin{array}{c}3.88 * * * \\
(0.24)\end{array}$ & $\begin{array}{c}3.87 * * * \\
(0.24)\end{array}$ & $\begin{array}{c}3.88 * * * \\
(0.24)\end{array}$ & $\begin{array}{c}3.87 * * * \\
(0.24)\end{array}$ & $\begin{array}{c}3.87 * * * \\
(0.24)\end{array}$ \\
\hline
\end{tabular}

a $* * *, * *, *$ indicates $1 \%, 5 \%$, and $10 \%$ significance levels, respectively. Robust standard errors in parenthesis. R-squared statistics for all regressions are 0.62 . Prohibition is measured as U.S. interdiction expenditure. Results reported lognormal estimates after dropping not statistically significant residuals from the estimation of prohibition. Mean of the unemployment rate and tariff rate are included as regressors (estimates not reported). We fail to reject the joint hypotheses that the prohibition and corresponding interaction effect are equal to zero at all significance levels for all regressions. 
Review of Economic Analysis 12 (2020) 271-319

Table 9. Cocaine-Coca Seizures Estimation (Lognormal Estimates; Continued) ${ }^{\text {a }}$

\begin{tabular}{|c|c|c|c|c|}
\hline Independent Variables & Coeff. & Coeff. & Coeff. & Coeff. \\
\hline Log(Prohibition) & $\begin{array}{l}-0.36 \\
(0.82)\end{array}$ & $\begin{array}{l}-1.58 \\
(2.42)\end{array}$ & $\begin{array}{c}1.12 \\
(0.84)\end{array}$ & $\begin{array}{l}0.55 \\
(0.64)\end{array}$ \\
\hline $\begin{array}{l}\text { Log(Prohibition) by } \\
\text { Openness }\end{array}$ & $\begin{array}{c}0.016 \\
(0.011)\end{array}$ & & & \\
\hline $\begin{array}{l}\log (\text { Prohibition }) \text { by } \\
\text { Economic Freedom }\end{array}$ & & $\begin{array}{c}0.036 \\
(0.039)\end{array}$ & & \\
\hline $\begin{array}{l}\log (\text { Prohibition) by Tariff } \\
\text { Rate }\end{array}$ & & & $\begin{array}{l}-0.07 \\
(0.11)\end{array}$ & \\
\hline $\begin{array}{l}\text { Log(Prohibition) by Internet } \\
\text { Access }\end{array}$ & & & & $\begin{array}{c}0.006 \\
(0.018)\end{array}$ \\
\hline Control-of-Corruption Index & $\begin{array}{l}-0.34 \\
(0.26)\end{array}$ & $\begin{array}{l}-0.32 \\
(0.26)\end{array}$ & $\begin{array}{l}-0.33 \\
(0.26)\end{array}$ & $\begin{array}{l}-0.32 \\
(0.26)\end{array}$ \\
\hline Unemployment Rate & $\begin{array}{l}-0.011 \\
(0.044)\end{array}$ & $\begin{array}{l}-0.026 \\
(0.045)\end{array}$ & $\begin{array}{l}-0.021 \\
(0.044)\end{array}$ & $\begin{array}{l}-0.019 \\
(0.043)\end{array}$ \\
\hline Relative Minimum Wage & $\begin{array}{l}0.027 * * * \\
(0.007)\end{array}$ & $\begin{array}{l}0.027 * * * \\
(0.0072)\end{array}$ & $\begin{array}{l}0.027 * * * \\
(0.0072)\end{array}$ & $\begin{array}{l}0.027 * * * \\
(0.0071)\end{array}$ \\
\hline Human Capital Index & $\begin{array}{l}1.87 * * * \\
(0.33)\end{array}$ & $\begin{array}{l}1.99 * * * \\
(0.35)\end{array}$ & $\begin{array}{l}1.92 * * * \\
(0.34)\end{array}$ & $\begin{array}{c}1.92 * * * \\
(0.34)\end{array}$ \\
\hline Openness & $\begin{array}{c}-0.13 \\
(0.085)\end{array}$ & $\begin{array}{l}-0.0033 \\
(0.003)\end{array}$ & $\begin{array}{l}-0.003 \\
(0.003)\end{array}$ & $\begin{array}{l}-0.0032 \\
(0.0029)\end{array}$ \\
\hline Economic Freedom & $\begin{array}{l}-0.029 * \\
(0.016)\end{array}$ & $\begin{array}{l}-0.31 \\
(0.31)\end{array}$ & $\begin{array}{l}-0.031 * \\
(0.016)\end{array}$ & $\begin{array}{c}-0.031 * \\
(0.017)\end{array}$ \\
\hline Tariff Rate & $\begin{array}{l}-0.029 \\
(0.053)\end{array}$ & $\begin{array}{c}-0.026 \\
(0.052)\end{array}$ & $\begin{array}{c}0.53 \\
(0.87)\end{array}$ & $\begin{array}{c}-0.026 \\
(0.054)\end{array}$ \\
\hline Internet Access & $\begin{array}{c}0.0024 \\
(0.01)\end{array}$ & $\begin{array}{r}-0.0031 \\
(0.011)\end{array}$ & $\begin{array}{l}0.0001 \\
(0.01) \\
\end{array}$ & $\begin{array}{c}-0.047 \\
(0.15)\end{array}$ \\
\hline Log(U.S. Cocaine Price) & $\begin{array}{l}-0.16 \\
(0.42)\end{array}$ & $\begin{array}{l}-0.017 \\
(0.42) \\
\end{array}$ & $\begin{array}{l}-0.11 \\
(0.42) \\
\end{array}$ & $\begin{array}{c}-0.092 \\
(0.41)\end{array}$ \\
\hline Big Country & $\begin{array}{c}3.88 * * * \\
(0.24)\end{array}$ & $\begin{array}{c}3.87 * * * \\
(0.24)\end{array}$ & $\begin{array}{c}3.88 * * * \\
(0.24)\end{array}$ & $\begin{array}{c}3.88 * * * \\
(0.24)\end{array}$ \\
\hline
\end{tabular}

a $* * *, * * *$ indicates $1 \%, 5 \%$, and $10 \%$ significance levels, respectively. Robust standard errors in parenthesis. R-squared statistics for all regressions are 0.62. Prohibition is measured as U.S. interdiction expenditure. Results reported lognormal estimates after dropping not statistically significant residuals from the estimation of prohibition. Mean of the unemployment rate and tariff rate are included as regressors (estimates not reported). We fail to reject the joint hypothesis that the prohibition and corresponding interaction effect is equal to zero at all significance levels for all regressions. 
SAENZ BARILLA New Approaches to U.S. Drug Policy

Table 10. Coca Cultivation Estimation (Lognormal Estimates) ${ }^{\mathrm{a}}$

\begin{tabular}{|c|c|c|c|c|c|c|c|}
\hline Independent Variables & Coeff. & Coeff. & Coeff. & Coeff. & Coeff. & Coeff. & Coeff. \\
\hline Residual & & & & & $\begin{array}{l}0.88 * * \\
(0.36) \\
\end{array}$ & & \\
\hline Log(Prohibition) & $\begin{array}{l}-0.15 \\
(0.11)\end{array}$ & $\begin{array}{c}-0.89 * * * \\
(0.27)\end{array}$ & $\begin{array}{c}-0.58 * * * \\
(0.16)\end{array}$ & $\begin{array}{c}-0.78 * * * \\
(0.21)\end{array}$ & $\begin{array}{l}1.82 * \\
(0.97)\end{array}$ & $\begin{array}{c}0.18 \\
(0.39)\end{array}$ & $\begin{array}{l}-0.95 \\
(1.42)\end{array}$ \\
\hline $\begin{array}{l}\text { Log(Prohibition) by } \\
\text { Control-of-Corruption } \\
\text { Index }\end{array}$ & & $\begin{array}{c}-2.28 * * * \\
(0.73)\end{array}$ & & & & & \\
\hline $\begin{array}{l}\text { Log(Prohibition) by } \\
\text { Unemployment Rate }\end{array}$ & & & $\begin{array}{c}0.048 * * * \\
(0.017)\end{array}$ & & & & \\
\hline $\begin{array}{l}\text { Log(Prohibition) by } \\
\text { Relative Minimum Wage }\end{array}$ & & & & $\begin{array}{c}0.039 * * * \\
(0.013)\end{array}$ & & & \\
\hline $\begin{array}{l}\text { Log(Prohibition) by } \\
\text { Human Capital Index }\end{array}$ & & & & & $\begin{array}{c}-1.18 * * * \\
(0.42)\end{array}$ & & \\
\hline $\begin{array}{l}\text { Log(Prohibition) by } \\
\text { Openness }\end{array}$ & & & & & & $\begin{array}{l}-0.0081 \\
(0.0084)\end{array}$ & \\
\hline $\begin{array}{l}\text { Log(Prohibition) by } \\
\text { Economic Freedom }\end{array}$ & & & & & & & $\begin{array}{c}0.012 \\
(0.022)\end{array}$ \\
\hline $\begin{array}{l}\text { Control-of-Corruption } \\
\text { Index }\end{array}$ & $\begin{array}{c}0.51 * * * \\
(0.19)\end{array}$ & $\begin{array}{c}16.8 * * * \\
(5.12)\end{array}$ & $\begin{array}{c}0.53 * * * \\
(0.18)\end{array}$ & $\begin{array}{c}0.43 * * * \\
(0.16)\end{array}$ & $\begin{array}{c}0.79 * * * \\
(0.22)\end{array}$ & $\begin{array}{c}0.58 * * * \\
(0.21)\end{array}$ & $\begin{array}{l}0.49 * * \\
(0.22)\end{array}$ \\
\hline Unemployment Rate & $\begin{array}{l}-0.0043 \\
(0.017)\end{array}$ & $\begin{array}{l}-0.018 \\
(0.016)\end{array}$ & $\begin{array}{c}-0.35 * * * \\
(0.12)\end{array}$ & $\begin{array}{c}0.012 \\
(0.013)\end{array}$ & $\begin{array}{l}0.051^{* *} \\
(0.022)\end{array}$ & $\begin{array}{l}-0.0019 \\
(0.017)\end{array}$ & $\begin{array}{l}-0.0034 \\
(0.017)\end{array}$ \\
\hline Relative Minimum Wage & $\begin{array}{l}0.054 * * * \\
(0.0099)\end{array}$ & $\begin{array}{c}0.077 * * * \\
(0.011)\end{array}$ & $\begin{array}{l}0.057 * * * \\
(0.0083)\end{array}$ & $\begin{array}{l}-0.23 * * \\
(0.099)\end{array}$ & $\begin{array}{l}0.068 * * * \\
(0.011)\end{array}$ & $\begin{array}{c}0.051 * * * \\
(0.011)\end{array}$ & $\begin{array}{c}0.053 * * * \\
(0.012)\end{array}$ \\
\hline Human Capital Index & $\begin{array}{c}-1.74 * * * \\
(0.32)\end{array}$ & $\begin{array}{c}-2.01 * * * \\
(0.22)\end{array}$ & $\begin{array}{c}-1.73 * * * \\
(0.27)\end{array}$ & $\begin{array}{c}-1.61 * * * \\
(0.25)\end{array}$ & $\begin{array}{l}7.73 * * \\
(3.13) \\
\end{array}$ & $\begin{array}{c}-1.71 * * * \\
(0.34)\end{array}$ & $\begin{array}{c}-1.77 * * * \\
(0.33)\end{array}$ \\
\hline Openness & $\begin{array}{l}-0.0037 \\
(0.0041)\end{array}$ & $\begin{array}{c}0.0013 \\
(0.0036)\end{array}$ & $\begin{array}{l}-0.00067 \\
(0.0036)\end{array}$ & $\begin{array}{l}-0.00081 \\
(0.0032) \\
\end{array}$ & $\begin{array}{l}0.015 * * \\
(0.007)\end{array}$ & $\begin{array}{c}0.055 \\
(0.061)\end{array}$ & $\begin{array}{l}-0.0032 \\
(0.0037)\end{array}$ \\
\hline Economic Freedom & $\begin{array}{l}-0.015 * * \\
(0.0071)\end{array}$ & $\begin{array}{l}-0.0098 \\
(0.0061)\end{array}$ & $\begin{array}{l}-0.014^{*} \\
(0.007)\end{array}$ & $\begin{array}{l}-0.015 * * \\
(0.0067)\end{array}$ & $\begin{array}{l}-0.0018 \\
(0.0082)\end{array}$ & $\begin{array}{c}-0.017 * * \\
(0.0074)\end{array}$ & $\begin{array}{l}-0.11 \\
(0.16)\end{array}$ \\
\hline Log(U.S. Cocaine Price) & $\begin{array}{c}0.58 * * * \\
(0.11)\end{array}$ & $\begin{array}{c}0.38 * * * \\
(0.12)\end{array}$ & $\begin{array}{c}0.58 * * * \\
(0.1)\end{array}$ & $\begin{array}{c}0.59 * * * \\
(0.11)\end{array}$ & $\begin{array}{c}0.84 * * * \\
(0.14)\end{array}$ & $\begin{array}{c}0.61 * * * \\
(0.11)\end{array}$ & $\begin{array}{c}0.58 * * * \\
(0.12)\end{array}$ \\
\hline R-Squared & 0.9 & 0.93 & 0.91 & 0.92 & 0.91 & 0.9 & 0.9 \\
\hline
\end{tabular}

a $* * *, * *, *$ indicates significant effects at the $1 \%, 5 \%$, and $10 \%$ significance level, respectively. Robust standard errors in parenthesis. Prohibition is measured as U.S. international expenditure. Results reported lognormal estimates obtained after dropping not statistically significant residuals from the estimation of prohibition. P-values for the joint hypotheses that the prohibition and $\mathrm{m}^{\text {th }}$ interaction effect equal to zero are: $0.004(\mathrm{~m}=$ controlof-corruption index interaction); $0.001(\mathrm{~m}=$ unemployment rate interaction); $0.0003(\mathrm{~m}=$ relative minimum wage interaction); 0.0008 ( $\mathrm{m}=$ human capital index interaction); $0.104(\mathrm{~m}$ $=$ openness interaction $)$; and $0.38(\mathrm{~m}=$ economic freedom interaction $)$. We fail to reject the Jarque-Bera test of normality at all standard significance levels for all regressions. 
Review of Economic Analysis 12 (2020) 271-319

Table 11. Potential Cocaine Production Estimation (Lognormal Estimates) ${ }^{\mathrm{a}}$

\begin{tabular}{|c|c|c|c|c|c|c|c|}
\hline $\begin{array}{l}\text { Independent } \\
\text { Variables }\end{array}$ & Coeff. & Coeff. & Coeff. & Coeff. & Coeff. & Coeff. & Coeff. \\
\hline Log(Prohibition) & $\begin{array}{c}-0.35 * * * \\
(0.099)\end{array}$ & $\begin{array}{c}-0.55^{*} \\
(0.3)\end{array}$ & $\begin{array}{c}-0.54 * * \\
(0.21)\end{array}$ & $\begin{array}{l}-0.5^{*} \\
(0.29)\end{array}$ & $\begin{array}{l}-0.11 \\
(1.12)\end{array}$ & $\begin{array}{l}0.0091 \\
(0.34)\end{array}$ & $\begin{array}{l}-0.24 \\
(1.42)\end{array}$ \\
\hline $\begin{array}{l}\text { Log(Prohibition) by } \\
\text { Control-of-Corruption } \\
\text { Index }\end{array}$ & & $\begin{array}{l}-0.75 \\
(0.74)\end{array}$ & & & & & \\
\hline $\begin{array}{l}\text { Log(Prohibition) by } \\
\text { Unemployment Rate }\end{array}$ & & & $\begin{array}{c}0.021 \\
(0.021)\end{array}$ & & & & \\
\hline $\begin{array}{l}\text { Log(Prohibition) by } \\
\text { Relative Minimum } \\
\text { Wage }\end{array}$ & & & & $\begin{array}{c}0.009 \\
(0.018)\end{array}$ & & & \\
\hline $\begin{array}{l}\text { Log(Prohibition) by } \\
\text { Human Capital Index }\end{array}$ & & & & & $\begin{array}{l}-0.1 \\
(0.47)\end{array}$ & & \\
\hline $\begin{array}{l}\text { Log(Prohibition) by } \\
\text { Openness }\end{array}$ & & & & & & $\begin{array}{r}-0.0087 \\
(0.0082)\end{array}$ & \\
\hline $\begin{array}{l}\text { Log(Prohibition) by } \\
\text { Economic Freedom }\end{array}$ & & & & & & & $\begin{array}{l}-0.0016 \\
(0.022)\end{array}$ \\
\hline $\begin{array}{l}\text { Control-of-Corruption } \\
\text { Index }\end{array}$ & $\begin{array}{l}0.41^{*} \\
(0.22)\end{array}$ & $\begin{array}{c}5.89 \\
(5.14)\end{array}$ & $\begin{array}{l}0.41^{*} \\
(0.21)\end{array}$ & $\begin{array}{l}0.39^{*} \\
(0.22)\end{array}$ & $\begin{array}{l}0.41^{*} \\
(0.22)\end{array}$ & $\begin{array}{l}0.48 * * \\
(0.2)\end{array}$ & $\begin{array}{c}0.38 \\
(0.25)\end{array}$ \\
\hline Unemployment Rate & $\begin{array}{l}0.044 * * \\
(0.022)\end{array}$ & $\begin{array}{c}0.04^{*} \\
(0.023)\end{array}$ & $\begin{array}{l}-0.11 \\
(0.16)\end{array}$ & $\begin{array}{l}0.049 * * \\
(0.021)\end{array}$ & $\begin{array}{l}0.044 * * \\
(0.021)\end{array}$ & $\begin{array}{l}0.047 * * \\
(0.021)\end{array}$ & $\begin{array}{l}0.044 * * \\
(0.022)\end{array}$ \\
\hline $\begin{array}{l}\text { Relative Minimum } \\
\text { Wage }\end{array}$ & $\begin{array}{l}0.046^{* * * *} \\
(0.01)\end{array}$ & $\begin{array}{l}0.05 * * * \\
(0.015)\end{array}$ & $\begin{array}{l}0.047 * * * \\
(0.0099)\end{array}$ & $\begin{array}{l}-0.019 \\
(0.13)\end{array}$ & $\begin{array}{c}0.046 * * * \\
(0.01)\end{array}$ & $\begin{array}{l}0.044 * * * \\
(0.011)\end{array}$ & $\begin{array}{l}0.047 * * * \\
(0.012)\end{array}$ \\
\hline Human Capital Index & $\begin{array}{c}0.17 \\
(0.31)\end{array}$ & $\begin{array}{c}0.11 \\
(0.31)\end{array}$ & $\begin{array}{c}0.18 \\
(0.29)\end{array}$ & $\begin{array}{c}0.21 \\
(0.29)\end{array}$ & $\begin{array}{c}0.89 \\
(3.34)\end{array}$ & $\begin{array}{l}0.21 \\
(0.3)\end{array}$ & $\begin{array}{c}0.16 \\
(0.32)\end{array}$ \\
\hline Openness & $\begin{array}{l}0.0027 \\
(0.005)\end{array}$ & $\begin{array}{c}0.0031 \\
(0.0052)\end{array}$ & $\begin{array}{c}0.0041 \\
(0.0051)\end{array}$ & $\begin{array}{c}0.0035 \\
(0.0051)\end{array}$ & $\begin{array}{l}0.0032 \\
(0.005)\end{array}$ & $\begin{array}{l}0.066 \\
(0.06)\end{array}$ & $\begin{array}{c}0.0026 \\
(0.0053)\end{array}$ \\
\hline Economic Freedom & $\begin{array}{c}-0.011 \\
(0.0088)\end{array}$ & $\begin{array}{c}-0.011 \\
(0.0086)\end{array}$ & $\begin{array}{c}-0.01 \\
(0.009)\end{array}$ & $\begin{array}{c}-0.011 \\
(0.0089)\end{array}$ & $\begin{array}{l}-0.011 \\
(0.0088)\end{array}$ & $\begin{array}{c}-0.014 \\
(0.0095)\end{array}$ & $\begin{array}{c}-0.00021 \\
(0.16)\end{array}$ \\
\hline $\begin{array}{l}\text { Log(U.S. Cocaine } \\
\text { Price) }\end{array}$ & $\begin{array}{l}0.16 \\
(0.15)\end{array}$ & $\begin{array}{c}0.13 \\
(0.17)\end{array}$ & $\begin{array}{c}0.16 \\
(0.15)\end{array}$ & $\begin{array}{l}0.16 \\
(0.15)\end{array}$ & $\begin{array}{c}0.16 \\
(0.15)\end{array}$ & $\begin{array}{c}0.19 \\
(0.15)\end{array}$ & $\begin{array}{c}0.15 \\
(0.15)\end{array}$ \\
\hline R-Squared & 0.69 & 0.71 & 0.69 & 0.69 & 0.69 & 0.7 & 0.69 \\
\hline
\end{tabular}

a $* * *, * *, *$ indicates significant effects at the $1 \%, 5 \%$, and $10 \%$ significance level, respectively. Robust standard errors in parenthesis. Prohibition is measured as U.S. international expenditure. Results reported lognormal estimates obtained after dropping not statistically significant residuals from the estimation of prohibition. P-values for the joint hypotheses that the prohibition and $\mathrm{m}^{\text {th }}$ interaction effect equal to zero are: $0.004(\mathrm{~m}=$ controlof-corruption index interaction); $0.0005(\mathrm{~m}=$ unemployment rate interaction); $0.0005(\mathrm{~m}=$ relative minimum wage interaction); $0.0015(\mathrm{~m}=$ human capital index interaction); 0.0008 $(\mathrm{m}=$ openness interaction $)$; and $0.0016(\mathrm{~m}=$ economic freedom interaction $)$. We fail to reject the Jarque-Bera test of normality at all standard significance levels for all regressions. 
SAENZ BARILLA New Approaches to U.S. Drug Policy

Table 12. Coca Eradication Estimation (Lognormal Estimates) ${ }^{a}$

\begin{tabular}{|c|c|c|c|c|c|c|c|}
\hline Independent Variables & Coeff. & Coeff. & Coeff. & Coeff. & Coeff. & Coeff. & Coeff. \\
\hline Residual & $\begin{array}{c}-2^{*} \\
(1.03)\end{array}$ & $\begin{array}{l}-1.96^{*} \\
(1.13)\end{array}$ & $\begin{array}{l}-1.92 * \\
(1.03)\end{array}$ & $\begin{array}{l}-1.99 * * \\
(1.003)\end{array}$ & & $\begin{array}{l}-1.93 * \\
(0.99)\end{array}$ & $\begin{array}{c}-1.83 * * \\
(0.87)\end{array}$ \\
\hline Log(Prohibition) & $\begin{array}{c}2.66^{* * *} \\
(0.95)\end{array}$ & $\begin{array}{c}1.93 \\
(1.32)\end{array}$ & $\begin{array}{l}2.04 * \\
(1.06)\end{array}$ & $\begin{array}{l}2.10 * * \\
(1.05)\end{array}$ & $\begin{array}{l}5.81 * * * \\
(1.88)\end{array}$ & $\begin{array}{l}4.51 * * * \\
(1.06)\end{array}$ & $\begin{array}{l}11.5 * * * \\
(3.36)\end{array}$ \\
\hline $\begin{array}{l}\log (\text { Prohibition) by } \\
\text { Control-of-Corruption Index }\end{array}$ & & $\begin{array}{l}-2.15^{*} \\
(1.25) \\
\end{array}$ & & & & & \\
\hline $\begin{array}{l}\text { Log(Prohibition) by } \\
\text { Unemployment Rate }\end{array}$ & & & $\begin{array}{c}0.06 \\
(0.047)\end{array}$ & & & & \\
\hline $\begin{array}{l}\text { Log(Prohibition) by } \\
\text { Relative Minimum Wage }\end{array}$ & & & & $\begin{array}{c}0.034 \\
(0.034)\end{array}$ & & & \\
\hline $\begin{array}{l}\text { Log(Prohibition) by Human } \\
\text { Capital Index }\end{array}$ & & & & & $\begin{array}{c}-2.11 * * * \\
(0.8)\end{array}$ & & \\
\hline $\begin{array}{l}\text { Log(Prohibition) by } \\
\text { Openness }\end{array}$ & & & & & & $\begin{array}{c}-0.049 * * * \\
(0.017)\end{array}$ & \\
\hline $\begin{array}{l}\text { Log(Prohibition) by } \\
\text { Economic Freedom }\end{array}$ & & & & & & & $\begin{array}{c}-0.14 * * * \\
(0.053)\end{array}$ \\
\hline Control-of-Corruption Index & $\begin{array}{c}-1.62 * * \\
(0.66)\end{array}$ & $\begin{array}{c}13.9 \\
(9.29)\end{array}$ & $\begin{array}{c}-1.63 * * * \\
(0.56)\end{array}$ & $\begin{array}{c}-1.69 * * * \\
(0.54)\end{array}$ & $\begin{array}{c}-0.995 * * \\
(0.49)\end{array}$ & $\begin{array}{l}-1.06^{*} \\
(0.55)\end{array}$ & $\begin{array}{c}-1.92 * * * \\
(0.48)\end{array}$ \\
\hline Unemployment Rate & $\begin{array}{c}-0.21 * * * \\
(0.069)\end{array}$ & $\begin{array}{c}-0.22 * * * \\
(0.077)\end{array}$ & $\begin{array}{l}-0.64 * \\
(0.33)\end{array}$ & $\begin{array}{l}-0.2 * * * \\
(0.075)\end{array}$ & $\begin{array}{l}-0.088 * * \\
(0.039)\end{array}$ & $\begin{array}{c}-0.18 * * \\
(0.08)\end{array}$ & $\begin{array}{l}-0.22 * * * \\
(0.059)\end{array}$ \\
\hline Relative Minimum Wage & $\begin{array}{l}0.12 * * * \\
(0.023)\end{array}$ & $\begin{array}{c}0.14 * * * \\
(0.02)\end{array}$ & $\begin{array}{l}0.13 * * * \\
(0.021)\end{array}$ & $\begin{array}{l}-0.13 \\
(0.26)\end{array}$ & $\begin{array}{l}0.15^{* * *} \\
(0.021)\end{array}$ & $\begin{array}{c}0.10 * * * \\
(0.02)\end{array}$ & $\begin{array}{l}0.14 * * * \\
(0.023)\end{array}$ \\
\hline Human Capital Index & $\begin{array}{c}-7.33 * * * \\
(1.35)\end{array}$ & $\begin{array}{c}-7.49 * * * \\
(1.45)\end{array}$ & $\begin{array}{c}-7.21 * * * \\
(1.43)\end{array}$ & $\begin{array}{c}-7.22 * * * \\
(1.37)\end{array}$ & $\begin{array}{l}10.1 * \\
(5.64)\end{array}$ & $\begin{array}{c}-6.86 * * * \\
(1.41)\end{array}$ & $\begin{array}{c}-6.94 * * * \\
(1.16)\end{array}$ \\
\hline Openness & $\begin{array}{c}-0.034^{*} \\
(0.02)\end{array}$ & $\begin{array}{l}-0.029 \\
(0.021)\end{array}$ & $\begin{array}{l}-0.029 \\
(0.02)\end{array}$ & $\begin{array}{l}-0.031 \\
(0.019)\end{array}$ & $\begin{array}{l}0.0077 \\
(0.011)\end{array}$ & $\begin{array}{l}0.32 * * \\
(0.13)\end{array}$ & $\begin{array}{c}-0.038^{* *} \\
(0.016)\end{array}$ \\
\hline Economic Freedom & $\begin{array}{l}-0.044^{*} \\
(0.025)\end{array}$ & $\begin{array}{c}-0.04 \\
(0.025)\end{array}$ & $\begin{array}{l}-0.041^{*} \\
(0.024)\end{array}$ & $\begin{array}{l}-0.044^{*} \\
(0.025)\end{array}$ & $\begin{array}{l}-0.015 \\
(0.019)\end{array}$ & $\begin{array}{c}-0.056^{* * *} \\
(0.018)\end{array}$ & $\begin{array}{c}0.98 * * \\
(0.39)\end{array}$ \\
\hline Log(U.S. Cocaine Price) & $\begin{array}{c}-0.24 \\
(0.37)\end{array}$ & $\begin{array}{l}-0.37 \\
(0.36)\end{array}$ & $\begin{array}{l}-0.23 \\
(0.39)\end{array}$ & $\begin{array}{l}-0.23 \\
(0.37)\end{array}$ & $\begin{array}{c}0.33 \\
(0.25)\end{array}$ & $\begin{array}{l}-0.03 \\
(0.38)\end{array}$ & $\begin{array}{l}-0.3 \\
(0.33)\end{array}$ \\
\hline R-Squared & 0.87 & 0.87 & 0.87 & 0.87 & 0.88 & 0.89 & 0.89 \\
\hline
\end{tabular}

a $* * *, * *, *$ indicates significant effects at the $1 \%, 5 \%$, and $10 \%$ significance level, respectively. Robust standard errors in parenthesis. Prohibition is measured as U.S. international expenditure. Results reported lognormal estimates obtained after dropping not statistically significant residuals from the estimation of prohibition. P-values for the joint hypotheses that the prohibition and $\mathrm{m}^{\text {th }}$ interaction effect equal to zero are: $0.0001(\mathrm{~m}=$ control-of-corruption index interaction); $0.008(\mathrm{~m}=$ unemployment rate interaction); 0.009 $(\mathrm{m}=$ relative minimum wage interaction $) ;<0.0001(\mathrm{~m}=$ human capital index interaction $)$; $0.0001(\mathrm{~m}=$ openness interaction $)$; and $0.0001(\mathrm{~m}=$ economic freedom interaction $)$. We fail to reject the Jarque-Bera test of normality at all standard significance levels for all regressions, except for the regression including the log (prohibition) by control-of-corruption index interaction for which we fail to reject the joint hypothesis at the 5\% significance level. 
Table 13. Summary of Significant Factors Affecting Illicit Drug Availability Indicators (Lognormal Estimates) ${ }^{\mathrm{a}}$

\begin{tabular}{|c|c|c|c|c|}
\hline & $\begin{array}{c}\log (\text { Cocaine- } \\
\text { Coca Seizures) }\end{array}$ & $\begin{array}{c}\log (\text { Coca } \\
\text { Cultivation })\end{array}$ & $\begin{array}{l}\text { Log(Potential } \\
\text { Cocaine } \\
\text { Production })\end{array}$ & $\begin{array}{c}\log (\text { Coca } \\
\text { Eradication })\end{array}$ \\
\hline & No. Obs. 360 & \multicolumn{3}{|c|}{$\begin{array}{c}\text { No. Obs. } 60 \text { (cultivation, potential production, } \\
\text { eradication) }\end{array}$} \\
\hline Independent Vars. & Coefficient & Coefficient & Coefficient & Coefficient \\
\hline Log(Prohibition) & & & $\begin{array}{c}-0.35 * * * \\
(0.099)\end{array}$ & $\begin{array}{c}2.66 * * * \\
(0.95)\end{array}$ \\
\hline \multicolumn{5}{|l|}{ Ownership Variable } \\
\hline $\begin{array}{l}\text { Control-of- } \\
\text { Corruption Index }\end{array}$ & & $\begin{array}{c}0.51 * * * \\
(0.19)\end{array}$ & $\begin{array}{l}0.41 * \\
(0.22)\end{array}$ & $\begin{array}{c}-1.62 * * \\
(0.66)\end{array}$ \\
\hline \multicolumn{5}{|l|}{ Location Variables } \\
\hline $\begin{array}{l}\text { Unemployment } \\
\text { Rate }\end{array}$ & & & $\begin{array}{l}0.044 * * \\
(0.022)\end{array}$ & $\begin{array}{c}-0.21 * * * \\
(0.069)\end{array}$ \\
\hline $\begin{array}{l}\text { Relative Minimum } \\
\text { Wage }\end{array}$ & $\begin{array}{l}0.027 * * * \\
(0.0071)\end{array}$ & $\begin{array}{l}0.054 * * * \\
(0.0099)\end{array}$ & $\begin{array}{c}0.046^{* * *} \\
(0.01)\end{array}$ & $\begin{array}{l}0.12 * * * \\
(0.023)\end{array}$ \\
\hline $\begin{array}{l}\text { Human Capital } \\
\text { Index }\end{array}$ & $\begin{array}{c}1.92 * * * \\
(0.34)\end{array}$ & $\begin{array}{c}-1.74 * * * \\
(0.32)\end{array}$ & & $\begin{array}{c}-7.33 * * * \\
(1.35)\end{array}$ \\
\hline Openness & & & & $\begin{array}{c}-0.034^{*} \\
(0.02)\end{array}$ \\
\hline \multicolumn{5}{|c|}{ Internalization Variables } \\
\hline $\begin{array}{l}\text { Economic } \\
\text { Freedom }\end{array}$ & $\begin{array}{l}-0.031 * \\
(0.017)\end{array}$ & $\begin{array}{l}-0.015 * * \\
(0.0071)\end{array}$ & & $\begin{array}{l}-0.044 * \\
(0.025)\end{array}$ \\
\hline \multicolumn{5}{|l|}{ Demand Proxy } \\
\hline $\begin{array}{l}\log (\text { U.S. Cocaine } \\
\text { Price) }\end{array}$ & & $\begin{array}{c}0.58 * * * \\
(0.11)\end{array}$ & & \\
\hline \multicolumn{5}{|c|}{ Large Producer Proxy } \\
\hline Big Country & $\begin{array}{c}3.88 * * * \\
(0.24)\end{array}$ & & & \\
\hline
\end{tabular}

a $* * *, * *, *$ indicates significant effects at the $1 \%, 5 \%$, and $10 \%$ significance level, respectively. Robust standard errors in parenthesis. Summary of results reported for regressions excluding interaction effects (i.e. first column of Table 9, Table 10, Table 11, and Table 12) 
SAENZ BARILLA New Approaches to U.S. Drug Policy

Table 14. Summary of Interaction Effects (Estimates Reported for Significant Joint Hypothesis of Prohibition and Interaction Effect) ${ }^{\mathrm{a}}$

\begin{tabular}{lccc}
\hline \multicolumn{1}{c}{ Dependent Variable } & $\begin{array}{c}\text { Log }(\text { Coca } \\
\text { Cultivation) }\end{array}$ & $\begin{array}{c}\text { Log (Potential } \\
\text { Cocaine Production) }\end{array}$ & $\begin{array}{c}\text { Log (Coca } \\
\text { Eradication) }\end{array}$ \\
\hline Coefficient & Coefficient & Coefficient \\
\hline Log(Prohibition) by & $-2.28^{* * *}$ & -0.75 & $-2.15^{*}$ \\
Control-of-Corruption & $(0.73)$ & $(0.74)$ & $(1.25)$ \\
Index & $0.048^{* * *}$ & 0.021 & 0.06 \\
\hline Log(Prohibition) by & $(0.017)$ & $(0.021)$ & $(0.047)$ \\
Unemployment Rate & $0.039^{* * *}$ & 0.009 & 0.034 \\
\hline Log(Prohibition) by & $(0.013)$ & $(0.018)$ & $(0.034)$ \\
Relative Minimum Wage & $-1.18^{* * *}$ & -0.1 & $-2.11^{* * *}$ \\
\hline Log(Prohibition) by & $(0.42)$ & $(0.47)$ & $(0.8)$ \\
Human Capital Index & & -0.0087 & $-0.049^{* * *}$ \\
\hline Log(Prohibition) by & & $(0.0082)$ & $(0.017)$ \\
Openness & & -0.0016 & $-0.14 * * *$ \\
\hline Log(Prohibition) by & & $(0.022)$ & $(0.053)$ \\
Economic Freedom & & &
\end{tabular}

a $* * *, * *, *$ indicates significant effects at the $1 \%, 5 \%$, and $10 \%$ significance level, respectively. Robust standard errors in parenthesis. Summary of results reported for significant joint hypotheses (Ho: prohibition $=\mathrm{m}^{\text {th }}$ interaction $=0$ ) from Table 10, Table 11, and Table 12). Joint hypotheses for the coca seizures regressions are not significant at all standard significance levels (see Table 9). Joint hypotheses for the coca cultivation, potential cocaine production, and coca eradication regressions are significant at the $1 \%$ significance level (see Table 10, Table 11, and Table 12).

production. In addition, tougher U.S. drug prohibition policy limits the impact that the controlof-corruption index, human capital, economic freedom, and openness have when dealing with on-site eradications.

Table 15 reports the economic and political impact of U.S. drug prohibition policy on real GDP growth and political stability in Latin America. ${ }^{41}$ Prohibition spending does not impact Latin American countries' economic growth, but it does create political instability for the region. When prohibition cuts off entrepreneurs from an importance source of income the intuitive belief is that individuals are incentivized to move legal transactions into the shadow economy. Unfortunately, that means they cannot use the legal court and judicial system, and violence is used as a form of enforcement. The inability to use the legal court and judicial

${ }^{41}$ Estimates reported in Table 15 were obtained from simultaneously estimating Real GDP growth and political stability, considering the correlation between the two dependent variables. 
Table 15. Impact of Prohibition on Latin American Countries' GDP Growth and Political Stability ${ }^{\text {a }}$

\begin{tabular}{|c|c|c|c|c|}
\hline & $\begin{array}{l}\text { Real GDP } \\
\text { Growth }\end{array}$ & $\begin{array}{l}\text { Political } \\
\text { Stability }\end{array}$ & $\begin{array}{l}\text { Real GDP } \\
\text { Growth }\end{array}$ & $\begin{array}{l}\text { Political } \\
\text { Stability }\end{array}$ \\
\hline & \multicolumn{2}{|c|}{ System 1} & \multicolumn{2}{|c|}{ System 2} \\
\hline Independent Variables & Coefficient & Coefficient & Coefficient & Coefficient \\
\hline $\begin{array}{l}\text { Log(Prohibition) - U.S. } \\
\text { Interdiction Expenditure }\end{array}$ & $\begin{array}{l}-0.89 \\
(0.89)\end{array}$ & $\begin{array}{c}-0.27 * * \\
(0.11)\end{array}$ & & \\
\hline $\begin{array}{l}\text { Log(Prohibition) - U.S. } \\
\text { International Expenditure }\end{array}$ & & & $\begin{array}{l}-0.27 \\
(0.42)\end{array}$ & $\begin{array}{l}-0.023 \\
(0.056)\end{array}$ \\
\hline $\begin{array}{l}\text { Control-of-Corruption } \\
\text { Index }\end{array}$ & $\begin{array}{c}1.08 \\
(0.88)\end{array}$ & $\begin{array}{l}0.18 * * \\
(0.091)\end{array}$ & $\begin{array}{c}1.04 \\
(0.88)\end{array}$ & $\begin{array}{c}0.15^{*} \\
(0.093)\end{array}$ \\
\hline Unemployment Rate & $\begin{array}{c}-0.39 * * * \\
(0.12)\end{array}$ & $\begin{array}{l}-0.025 * * \\
(0.0098)\end{array}$ & $\begin{array}{c}-0.39 * * * \\
(0.11)\end{array}$ & $\begin{array}{l}-0.024 * * \\
(0.0098)\end{array}$ \\
\hline Relative Minimum Wage & $\begin{array}{l}-0.011 \\
(0.027)\end{array}$ & $\begin{array}{l}-0.017 * * * \\
(0.0031)\end{array}$ & $\begin{array}{c}-0.01 \\
(0.028)\end{array}$ & $\begin{array}{c}-0.017 * * * \\
(0.0033)\end{array}$ \\
\hline Human Capital Index & $\begin{array}{c}0.57 \\
(1.03)\end{array}$ & $\begin{array}{l}-0.053 \\
(0.13)\end{array}$ & $\begin{array}{c}0.54 \\
(1.05)\end{array}$ & $\begin{array}{l}-0.087 \\
(0.14)\end{array}$ \\
\hline Openness & $\begin{array}{l}0.032 * * * \\
(0.0066)\end{array}$ & $\begin{array}{c}0.0049 * * * \\
(0.00077)\end{array}$ & $\begin{array}{l}0.032 * * * \\
(0.0067)\end{array}$ & $\begin{array}{l}0.0048 * * * \\
(0.00081)\end{array}$ \\
\hline Log(Distance) & $\begin{array}{l}-0.12 \\
(0.71)\end{array}$ & $\begin{array}{c}0.49 * * * \\
(0.073)\end{array}$ & $\begin{array}{c}-0.1 \\
(0.71)\end{array}$ & $\begin{array}{l}0.51 * * * \\
(0.076)\end{array}$ \\
\hline Economic Freedom & $\begin{array}{c}-0.075 * * \\
(0.032)\end{array}$ & $\begin{array}{l}-0.011 * * * \\
(0.0035)\end{array}$ & $\begin{array}{c}-0.073 * * \\
(0.032)\end{array}$ & $\begin{array}{l}-0.011 * * * \\
(0.0035)\end{array}$ \\
\hline Tariff Rate & $\begin{array}{l}-0.15^{*} \\
(0.088)\end{array}$ & $\begin{array}{c}-0.00074 \\
(0.01)\end{array}$ & $\begin{array}{c}-0.13 \\
(0.087)\end{array}$ & $\begin{array}{l}0.0095 \\
(0.01)\end{array}$ \\
\hline Internet Access & $\begin{array}{c}0.028 \\
(0.026)\end{array}$ & $\begin{array}{l}0.0072 * * \\
(0.0032)\end{array}$ & $\begin{array}{c}0.026 \\
(0.026)\end{array}$ & $\begin{array}{l}0.007 * * \\
(0.0032)\end{array}$ \\
\hline Big Country & $\begin{array}{c}1.44 * * * \\
(0.44)\end{array}$ & $\begin{array}{l}-0.73 * * * \\
(0.059)\end{array}$ & $\begin{array}{c}1.43 * * * \\
(0.45)\end{array}$ & $\begin{array}{c}-0.73 * * * \\
(0.06)\end{array}$ \\
\hline R-Squared & & & & \\
\hline
\end{tabular}

a $* * *, * *, *$ indicates significant effects at the $1 \%, 5 \%$, and $10 \%$ significance level, respectively. Robust standard errors in parenthesis. System 1 and System 2 indicate the simultaneous regression of real GDP growth and political stability on prohibition, Ownership, Location, and Internalization characteristics. System 1 measures prohibition as U.S interdiction expenditure. System 2 measures prohibition as U.S. international expenditure. Both System 1 and System 2 account for the correlation between real GDP growth and political stability. Results reported lognormal estimates obtained after dropping not statistically significant residuals from the estimation of prohibition. Mean of the unemployment rate, tariff rate, and internet access are included as regressors (estimates not reported).

system means that bribes are used as an incentive for getting the cooperation of government officials, and threat of violence is used to induce cooperation, eroding the role of the 
SAENZ BARILLA New Approaches to U.S. Drug Policy

government as enforcer of law and order (Nadelmann, 1988). In the Americas, most countries have a direct relationship between the cocaine market and violence (United National Office of Drugs and Crime (UNODC), 2008, 2010a). In Colombia, approximately 40 percent of the homicides have resulted from drug production activities (Organization of American States (OAS), 2013b) and in Guatemala, Honduras, El Salvador, and Mexico murder rates are consistently higher in areas related to cocaine drug trafficking (United National Office of Drugs and Crime (UNODC), 2008, 2010b). Unfortunately, successful prohibition policies in one country have been found to increase violence and drug trafficking in other countries (Mejia and Restrepo, 2014).

\subsection{Robustness Checks}

A sensitivity analysis is provided as support of the superiority of the MLMV and Multiple Imputation analysis as econometric techniques when estimating the impact of U.S. drug prohibition policy on illicit supply indicators, real GDP growth, and political stability in comparison to a complete case analysis. Under the assumption that data is MAR, complete case analysis leads to biased estimators and large standard errors (Newman, 2014). Newman (2014) points that using Maximum Likelihood and Multiple Imputation techniques to deal with missing values when data is MAR, produces unbiased estimators and accurate standard errors.

Table 16 provides the estimation of illicit drug supply indicators, real GDP growth, and political stability using complete case analysis. As shown in Table 16, the standard errors of the parameters estimators are larger than those produced by the MLMV and Multiple Imputation analysis. ${ }^{42}$ The MLMV and Multiple Imputation analysis produce more efficient estimators when data is MAR. In addition, the imputed data sets, in the Multiple Imputation analysis, showed the mean and standard deviation for the variables with missing observations to be approximately the same as their mean and standard deviation in the original data set. ${ }^{43}$

\section{Conclusions}

U.S. drug prohibition policy in the Americas is examined in conjunction with the factors driving Transnational Criminal Enterprises locational decisions in the cocaine-coca market using Dunning's Eclectic Paradigm for international business. Drug prohibition programs yield ambiguous results for both local governments and Transnational Criminal Enterprises. Understanding the site/situational specific characteristics can lead to more efficient prohibition programs by successfully limiting cocaine supply as well as restricting profitable business opportunities for Transnational Criminal Enterprises.

\footnotetext{
${ }^{42}$ As presented in Table 9 through Table 15.

${ }^{43}$ Tables can be provided upon request. These tables were omitted for brevity.
} 
Review of Economic Analysis 12 (2020) 271-319

Table 16. Estimation Using Complete Case Analysis ${ }^{a}$

\begin{tabular}{|c|c|c|c|c|}
\hline & Log(Seizures) & $\begin{array}{c}\log (\text { Coca } \\
\text { Cultivation })\end{array}$ & $\begin{array}{l}\text { Log(Potential } \\
\text { Cocaine } \\
\text { Production }) \\
\end{array}$ & $\begin{array}{c}\log (\text { Coca } \\
\text { Eradication })\end{array}$ \\
\hline $\begin{array}{l}\text { Independent } \\
\text { Variables }\end{array}$ & & Coeff. & Coeff. & Coeff. \\
\hline Residual & --- & --- & --- & $\begin{array}{l}-1.61 \\
(1.11)\end{array}$ \\
\hline $\begin{array}{l}\text { Log(Prohibition) - U.S. } \\
\text { Interdiction } \\
\text { Expenditure }\end{array}$ & $\begin{array}{l}1.3^{*} \\
(0.68)\end{array}$ & --- & --- & --- \\
\hline $\begin{array}{l}\text { Log(Prohibition) - U.S. } \\
\text { International } \\
\text { Expenditure }\end{array}$ & --- & $\begin{array}{l}-0.11 \\
(0.14)\end{array}$ & $\begin{array}{c}-0.23 * * \\
(0.11)\end{array}$ & $\begin{array}{l}2.23 * * \\
(1.05)\end{array}$ \\
\hline $\begin{array}{l}\text { Control-of-Corruption } \\
\text { Index }\end{array}$ & $\begin{array}{l}-0.24 \\
(0.27)\end{array}$ & $\begin{array}{c}0.55^{* * *} \\
(0.21)\end{array}$ & $\begin{array}{l}0.48 * * \\
(0.19) \\
\end{array}$ & $\begin{array}{l}-1.5 * * \\
(0.62) \\
\end{array}$ \\
\hline Unemployment Rate & $\begin{array}{l}-0.019 \\
(0.054)\end{array}$ & $\begin{array}{l}-0.006 \\
(0.021)\end{array}$ & $\begin{array}{l}0.034 \\
(0.03)\end{array}$ & $\begin{array}{l}-0.17 * * \\
(0.084)\end{array}$ \\
\hline $\begin{array}{l}\text { Relative Minimum } \\
\text { Wage }\end{array}$ & $\begin{array}{l}0.025 * * * \\
(0.0082)\end{array}$ & $\begin{array}{c}0.052 * * * \\
(0.011)\end{array}$ & $\begin{array}{c}0.042^{* * *} \\
(0.011)\end{array}$ & $\begin{array}{l}0.13 * * * \\
(0.025)\end{array}$ \\
\hline Human Capital Index & $\begin{array}{l}1.92 * * * \\
(0.37)\end{array}$ & $\begin{array}{c}-1.7 * * * \\
(0.37)\end{array}$ & $\begin{array}{c}0.24 \\
(0.32)\end{array}$ & $\begin{array}{c}-6.56 * * * \\
(1.45)\end{array}$ \\
\hline Openness & $\begin{array}{l}-0.0034 \\
(0.0034)\end{array}$ & $\begin{array}{l}-0.0049 \\
(0.0052)\end{array}$ & $\begin{array}{l}-0.0029 \\
(0.0056)\end{array}$ & $\begin{array}{l}-0.025 \\
(0.022)\end{array}$ \\
\hline Economic Freedom & $\begin{array}{l}-0.025 \\
(0.02)\end{array}$ & $\begin{array}{l}-0.015^{*} \\
(0.0078)\end{array}$ & $\begin{array}{l}-0.016^{*} \\
(0.0095)\end{array}$ & $\begin{array}{l}-0.044^{*} \\
(0.025)\end{array}$ \\
\hline Tariff Rate & $\begin{array}{c}0.017 \\
(0.061)\end{array}$ & -- & -- & -- \\
\hline Internet Access & $\begin{array}{l}-0.0035 \\
(0.013)\end{array}$ & --- & --- & --- \\
\hline $\begin{array}{l}\text { Log(U.S. Cocaine } \\
\text { Price) }\end{array}$ & $\begin{array}{l}-0.0088 \\
(0.46)\end{array}$ & $\begin{array}{c}0.58 * * * \\
(0.12)\end{array}$ & $\begin{array}{c}0.14 \\
(0.15)\end{array}$ & $\begin{array}{l}-0.13 \\
(0.38)\end{array}$ \\
\hline Big Country & $\begin{array}{c}4.001 * * * \\
(0.25)\end{array}$ & --- & --- & --- \\
\hline No. Obs. & 268 & 50 & 50 & 50 \\
\hline
\end{tabular}

a $* * *, * *, *$ indicates significant effects at the $1 \%, 5 \%$, and $10 \%$ significance level, respectively. Robust standard errors in parenthesis. 
SAENZ BARILLA New Approaches to U.S. Drug Policy

Table 16. Estimation Using Complete Case Analysis (Continued) ${ }^{a}$

\begin{tabular}{|c|c|c|c|c|}
\hline & $\begin{array}{c}\text { Real GDP } \\
\text { Growth }\end{array}$ & $\begin{array}{l}\text { Political } \\
\text { Stability }\end{array}$ & $\begin{array}{l}\text { Real GDP } \\
\text { Growth }\end{array}$ & $\begin{array}{l}\text { Political } \\
\text { Stability }\end{array}$ \\
\hline & \multicolumn{2}{|c|}{ System 1} & \multicolumn{2}{|c|}{ System 2} \\
\hline Independent Variables & Coeff. & Coeff. & Coeff. & Coeff. \\
\hline $\begin{array}{l}\text { Log(Prohibition) - U.S. } \\
\text { Interdiction Expenditure }\end{array}$ & $\begin{array}{c}0.12 \\
(1.26)\end{array}$ & $\begin{array}{c}-0.44 * * * \\
(0.14)\end{array}$ & --- & --- \\
\hline $\begin{array}{l}\text { Log(Prohibition) - U.S. } \\
\text { International Expenditure }\end{array}$ & --- & --- & $\begin{array}{c}0.37 \\
(0.62)\end{array}$ & $\begin{array}{l}-0.034 \\
(0.073)\end{array}$ \\
\hline Control-of-Corruption Index & $\begin{array}{c}1.01 \\
(0.95)\end{array}$ & $\begin{array}{c}0.24 * * \\
(0.1)\end{array}$ & $\begin{array}{c}0.93 \\
(0.93)\end{array}$ & $\begin{array}{l}0.18^{*} \\
(0.11)\end{array}$ \\
\hline Unemployment Rate & $\begin{array}{c}-0.36^{* *} \\
(0.16)\end{array}$ & $\begin{array}{l}-0.02 * \\
(0.012)\end{array}$ & $\begin{array}{c}-0.36^{* *} \\
(0.16)\end{array}$ & $\begin{array}{l}-0.02 * \\
(0.012)\end{array}$ \\
\hline Relative Minimum Wage & $\begin{array}{c}-0.0082 \\
(0.03)\end{array}$ & $\begin{array}{l}-0.016 * * * \\
(0.0033)\end{array}$ & $\begin{array}{l}-0.011 \\
(0.031)\end{array}$ & $\begin{array}{c}-0.017 * * * \\
(0.0038)\end{array}$ \\
\hline Human Capital Index & $\begin{array}{l}-0.33 \\
(1.07)\end{array}$ & $\begin{array}{l}-0.009 \\
(0.14)\end{array}$ & $\begin{array}{l}-0.43 \\
(1.1)\end{array}$ & $\begin{array}{l}-0.06 \\
(0.15)\end{array}$ \\
\hline Openness & $\begin{array}{c}0.04 * * * \\
(0.007)\end{array}$ & $\begin{array}{c}0.0042 * * * \\
(0.00076)\end{array}$ & $\begin{array}{l}0.04 * * * \\
(0.0071)\end{array}$ & $\begin{array}{l}0.004 * * * \\
(0.00082)\end{array}$ \\
\hline $\log ($ Distance $)$ & $\begin{array}{c}0.28 \\
(0.84)\end{array}$ & $\begin{array}{l}0.46 * * * \\
(0.078)\end{array}$ & $\begin{array}{c}0.34 \\
(0.84)\end{array}$ & $\begin{array}{l}0.5 * * * \\
(0.083)\end{array}$ \\
\hline Economic Freedom & $\begin{array}{l}-0.07 * \\
(0.036)\end{array}$ & $\begin{array}{c}-0.012 * * * \\
(0.0035)\end{array}$ & $\begin{array}{l}-0.07 * \\
(0.036)\end{array}$ & $\begin{array}{c}-0.0098 * * * \\
(0.0036)\end{array}$ \\
\hline Tariff Rate & $\begin{array}{l}-0.13 \\
(0.1)\end{array}$ & $\begin{array}{c}-0.0045 \\
(0.01)\end{array}$ & $\begin{array}{c}-0.11 \\
(0.099)\end{array}$ & $\begin{array}{c}0.01 \\
(0.0099)\end{array}$ \\
\hline Internet Access & $\begin{array}{c}0.031 \\
(0.032)\end{array}$ & $\begin{array}{c}0.0081 * * \\
(0.0039)\end{array}$ & $\begin{array}{c}0.034 \\
(0.032)\end{array}$ & $\begin{array}{l}0.0067 * \\
(0.0039)\end{array}$ \\
\hline Log(U.S. Cocaine Price) & $\begin{array}{c}-4.71 * * * \\
(1.02)\end{array}$ & $\begin{array}{l}-0.094 \\
(0.12)\end{array}$ & $\begin{array}{l}-4.86 * * * \\
(1.0001)\end{array}$ & $\begin{array}{r}-0.047 \\
(0.12)\end{array}$ \\
\hline Big Country & $\begin{array}{c}1.72 * * * \\
(0.48)\end{array}$ & $\begin{array}{c}-0.74 * * * \\
(0.063)\end{array}$ & $\begin{array}{c}1.73 * * * \\
(0.49)\end{array}$ & $\begin{array}{c}-0.73 * * * \\
(0.065)\end{array}$ \\
\hline No. Obs. & & & & \\
\hline
\end{tabular}

a $* * *, * *, *$ indicates significant effects at the $1 \%, 5 \%$, and $10 \%$ significance level, respectively. Robust standard errors in parenthesis.

Our results indicate that tougher U.S. drug prohibition policy significantly decreases cocaine-coca at the source by decreasing potential cocaine production and increasing coca eradication. However, successful on-site efforts to decrease cocainecoca supply can also be hindered by tougher U.S. drug prohibition policy. Tougher U.S. drug prohibition policy generates advantages for Transnational Criminal Enterprises, by amplifying the impact of the Location variables (unemployment and local wages) on cocaine-coca production increases. More aggressive U.S. drug prohibition policy also generates advantages to Transnational Criminal 
Enterprises by limiting the impact of Ownership (control-of-corruption index) and Internalization (economic freedom) variables at increasing eradication efforts.

Successful drug prohibition policies must be designed in conjunction with the Ownership, Location and Internalization variables, and be directed towards outcomes that prove to be disadvantageous to Transnational Criminal Enterprises. Specifically, our results indicate that it is disadvantageous for Transnational Criminal Enterprises when the local unemployment rate decreases, human capital increases, and greater economic freedom exist as these Location and Internalization variables reduce cocaine-coca production. Furthermore, drug prohibition policies should go in hand with policies aimed at reducing demand as well, thus lowering U.S. retail price of cocaine and reducing coca cultivation.

Since unlimited prohibition spending does not exist, the model's results signal a sitespecific approach to prohibition policy. For example, U.S. drug prohibition policy should focus on reducing cocaine-coca on-site production while at the same time allocating resources designed to disincentivize farmers' participation in illicit economies. Our results indicate that developing rural farming communities through reducing unemployment and improving economic freedom, is expected to reduce cocaine-coca production on-site. Greater economic freedom results from improving the formalization of land and greater business, labor, and monetary freedom. In addition, U.S. drug prohibition policy should be combined with risk minimization policies for farmers. Stability and access to market resources are important determinants of the farmer's decision to participate in an illicit economy (Felbab-Brown, 2014). As evidenced by the success of Thailand in 2012, a wellmanaged and well-funded comprehensive rural development program accompanied with the generation of employment opportunities reduced poppy cultivation (Felbab-Brown, 2014).

U.S. drug prohibition policy has also shown to have negative externalities, by increasing the political instability for Latin America. The benefit to consumer countries through the diminished accessibility of the illicit drugs is derived from the transfer of prohibition costs to producer and transit countries (Collins, 2014). The negative impact that U.S. drug prohibition policy has had on the political stability for Latin America, means alternative approaches need to be considered.

One potential approach would be to legalize cocaine while designing programs that deal with drug consumption strictly from the consumer perspective. These programs need to provide information on all the effects of drug use. Niskanen (1992) indicates that consumption reduction is possible under legalization by making information of the effects of drug use broadly available. Niskanen (1992) reported that beginning in 1885 cocaine was sold in a variety of products. In 1906, the Pure Food and Drug Act began requiring the identification of specific drugs on the label of patent medicines. This approach successfully decreased the use of cocaine before its use was prohibited (Niskanen, 1992). Another alternative approach to prohibition policy would be to treat drug use as a public-health problem, instead of focusing on 
enforcement. During the Nixon Administration, the only time in the U.S. history of its war on drugs, most of the funding for drug policy went towards treatment, rather than law enforcement. The program quickly reverted funding back to prohibition before any significant results were uncovered (WGBH Educational Foundation, 2014). Niskanen (1992) points out that the Netherlands provides drug users with treatment and counseling, and users are not prosecuted for possession of small amounts of illicit drugs, while criminal prosecution is directed to major suppliers. The results of this program have been smaller usage rates of illicit drugs among teenagers compared to the U.S. and lower violent crime rates. Despite discussing the likely effects of cocaine legalization from indirect inference, Niskanen (1992) concludes that illicit drug legalization will significantly reduce the price and increase demand. There is no onesize-fits-all approach that policy makers can use that always results in reducing cocaine supply. U.S. drug prohibition policy becomes a balancing act between Ownership, Location and Internalization variables, eradication efforts, and pursuing programs that reduce either current or potential cocaine production.

\section{References}

Alesina, A., Özler, S., Roubini, N., \& Swagel, P. (1996). Political Instability and Economic Growth. Journal of Economic Growth, 1(2), 189-211. https://doi.org/10.1017/CBO9781107415324.004

Allison, P. D. (2010). Missing Data. In Handbook of Survey Research, Second Edition (pp. 631-657). Emerald Group Publishing Limited.

Andreas, P. (2000). Border Games: Policing the U.S. Mexico Divide. Ithaca, NY: Cornell University Press.

Banco de la República de Colombia. (2018). Salarios. Retrieved July 13, 2018, from http://www.banrep.gov.co/es/mercado-laboral/salarios

Berlusconi, G., Aziani, A., \& Giommoni, L. (2017). The Determinants of Heroin Flows in Europe: A Latent Space Approach. Social Networks, 51, 104-117. https://doi.org/10.1016/j.socnet.2017.03.012

Bonnie, R. J., \& Whitebread, C. H. (1970). The Forbidden Fruit and the Tree of Knowledge: An Inquiry into the Legal History of American Marijuana Prohibition. Virginia Law Review, 56(6), 971-1203.

Booth, A. L., \& Frank, J. (1999). Earnings, Productivity, and Performance-Related Pay. Journal of Labor Economics, 17(3), 447-463.

Boyum, D., \& Reuter, P. (2005). Current Policies. In An Analytic Assessment of U.S. Drug Policy. Washington, D.C.: AEI Press.

Buckley, P. J. (1993). The Role of Management in Internalisation Theory. Management International Review, 33(3), 197-207. 
Bureau for International Narcotics and Law Enforcement Affairs. (2017). International Narcotics Control Strategy Report: Drug and Chemical Control (Vol. I). Retrieved from https://books.google.com/books?id=0jnyNWFuhXYC\&pgis=1

Butler, K. C., \& Castelo, D. (1998). A Note on Political Risk and the Required Return on Foreign Direct Investment. Journal of International Business Studies, 29(3), 599-608.

Cadot, O. (1987). Corruption as a Gamble. Journal of Public Economics, 33, 223-244.

Cantwell, J., \& Narula, R. (2001). The Eclectic Paradigm in the Global Economy. International Journal of the Economics of Business, 8(2), 155-172. https://doi.org/10.1080/13571510110051504

Caulkins, J. P. (2014). Effects of Prohibition, Enforcement and Interdiction on Drug Use. Ending the Drug Wars: Report of the LSE Expert Group on the Economics of Drug Policy, $16-25$.

Caulkins, J. P., \& Reuter, P. (2010). How Drug Enforcement Affects Drug Prices. Crime and Justice, 39(1), 213-271. https://doi.org/10.1086/652386

Collins, J. (2014). The Economics of a New Global Strategy. Ending the Drug Wars: Report of the LSE Expert Group on the Economics of Drug Policy.

Courtwright, D. T. (2004). The Controlled Substances Act: How a "Big Tent" Reform Became a Punitive Drug Law. Drug and Alcohol Dependence, 76(1), 9-15. https://doi.org/10.1016/j.drugalcdep.2004.04.012

Datosmacro. (2018). Salario Mínimo Interprofesional. Retrieved June 28, 2018, from https://www.datosmacro.com

Dell'Anno, R., \& Solomon, O. H. (2008). Shadow Economy and Unemployment Rate in USA: Is There a Structural Relationship? An Empirical Analysis. Applied Economics, 40(19), 2537-2555. https://doi.org/10.1080/00036840600970195

Dunning, J. H. (1977). Trade, Location of Economic Activity and the Multinational Enterprise: A Search for an Eclectic Approach. In P.-O. Hesselborn, B. Ohlin, \& P. M. Wijkman (Eds.), The International Allocation of Economic Activity. Springer.

Dunning, J. H. (1988a). Explaining International Production. London: Unwin Hyman.

Dunning, J. H. (1988b). The Eclectic Paradigm of International Production : A Restatement and Some Possible Extensions. Journal of International Business Studies, 19(1), 1-31.

Dunning, J. H. (1996). The Geographical Sources of the Competitiveness of Firms: Some Results of a New Survey. Transnational Corporations, 5(3), 1-30.

Dunning, J. H. (2000). The Eclectic Paradigm as an Envelope for Economic and Business Theories of MNE activity. International Business Review, 9, 163-190.

Dunning, J. H. (2001). The Eclectic (OLI) Paradigm of International Production : Past, Present and Future. International Journal of the Economics of Business, 8(2), 173-190. https://doi.org/10.1080/13571510110051441 
SAENZ BARILLA New Approaches to U.S. Drug Policy

Dunning, J. H. (2009). Location and the Multinational Enterprise : John Dunning's thoughts on Receiving the "Journal of International Business Studies" 2008 Decade Award. Journal of International Business Studies, 40(1), 20-34. https://doi.org/10.1057/jibs.2008.75

Dunning, J. H., \& McKaig-Berliner, A. (2002). The Geographical Sources of Competitiveness: The Professional Business Services Industry. Transnational Corporations, 11(3), 1-38.

Enderwick, P. (2009). Applying the Eclectic Framework: The Strategy of Transnational Criminal Enterprises in the Global Era. Critical Perspectives on International Business, 5(3), 170-186. https://doi.org/10.1108/17422040910974677

Enderwick, P. (2016). The Transnational Organisation of the Drugs Trade. In Financial Crimes: Psychological, Technological, and Ethical Issues (pp. 309-327). Springer International Publishing. https://doi.org/10.1007/978-3-319-32419-7

Enste, D. H. (2010). Regulation and Shadow Economy: Empirical Evidence for 25 OECDCountries. Constitutional Political Economy, 21(3), 231-248. https://doi.org/10.1007/s10602-009-9081-9

Feenstra, R. C., Inklaar, R., \& Timmer, M. P. (2013). The Next Generation of the Penn World Table. American Economic Review, 105(10), 3150-3182. https://doi.org/10.15141/S5J01T

Felbab-Brown, V. (2014). Improving Supply-Side Policies: Smarter Eradication, Interdiction, and Alternative Livelihoods - and the Possibility of Licensing. Ending the Drug Wars: Report of the LSE Expert Group on the Economics of Drug Policy, 41-48.

Financial Action Task Force (FATF). (2006). Trade based money laundering. Trade Based Money Laundering (Vol. 9789264018). https://doi.org/10.1787/9789264018082-en

Gill, M. M. (2008). Correcting Course: Lessons from the 1970 Repeal of Mandatory Minimums. Federal Sentencing Reporter, 21(1), 55-68. https://doi.org/10.1525/fsr.2008.21.1.55

Giommoni, L., Aziani, A., \& Berlusconi, G. (2017). How Do Illicit Drugs Move Across Countries? A Network Analysis of the Heroin Supply to Europe. Journal of Drug Issues, 47(2), 217-240. https://doi.org/10.1177/0022042616682426

Gould, E. D., Weinberg, B. A., \& Mustard, D. B. (2002). Crime Rates and Local Labor Market Opportunities in the United States : 1979-1997. The Review of Economics and Statistics, 84(1), 45-61.

Howell, J. C., \& Decker, S. H. (1999). The Youth Gangs, Drugs and Violence Connection. Juvenile Justice Bulletin. Retrieved https://books.google.com/books?hl=en\&lr=\&id=V4BIAgAAQBAJ\&pgis=1

Independence Hall Association. (2019). American Political Attitudes and Participation. Retrieved April 6, 2020, from https://www.ushistory.org/gov/4b.asp

Instituto Nacional de Estadística (INE). (2018). Estadísticas del Mercado Laboral. Retrieved November 3, 2017, from https://www.ine.gob.bo/index.php/mercado-laboral/introduccion5 
International Labour Organization (ILO). (2018). Key Indicators of the Labour Market (KILM). Retrieved July 13, 2017, from http://www.ilo.org/ilostat

Keck, M., \& Correa-Cabrera, G. (2015). U.S. Drug Policy and Supply Side Strategies: Assessing Effectiveness and Results. Norteamérica, 10(2), 47-67. https://doi.org/10.20999/nam.2015.b002

Kim, S. (1996). How Trade Liberalization Affects the Political and Economic Performance of Developing Countries: The Application of a Two-Stage Game Model. Asian Perspective, 20(1), 163-184. Retrieved from http://www.jstor.org/stable/42704093

Lavorgna, A. (2014). Internet-Mediated Drug Trafficking: Towards a Better Understanding of New Criminal Dynamics. Trends in Organized Crime, 17(4), 250-270. https://doi.org/10.1007/s12117-014-9226-8

Lochner, L. (2004). Education, Work, and Crime: A Human Capital Approach. International Economic Review, 45(3), 811-843.

Mansfield, E. D., \& Pevehouse, J. C. (2000). Trade Blocs, Trade Flows, and International Conflict. International Organization, 54(4), 775-808. https://doi.org/10.4337/9781849808323.00037

McCann, P., \& Mudambi, R. (2004). The Location Behavior of the Multinational Enterprise : Some Analytical Issues. Growth and Change, 35(4), 491-524.

Mejia, D., \& Restrepo, P. (2014). Why is Strict Prohibition Collapsing? A Perspective from Producer and Transit Countries. Ending the Drug Wars: Report of the LSE Expert Group on the Economics of Drug Policy, 26-32.

Miron, J. A., \& Zwiebel, J. (1995). The Economic Case against Drug Prohibition. The Journal of Economic Perspectives, 9(4), 175-192.

Moore, M. H. (1990). Supply Reduction and Drug Law Enforcement. Crime and Justice, 13, 109-157.

Mudambi, R., \& Paul, C. (2003). Domestic Drug Prohibition as a Source of Foreign Institutional Instability: An Analysis of the Multinational Extralegal Enterprise. Journal of International Management, 9(3), 335-349. https://doi.org/10.1016/S1075-4253(03)00053$\mathrm{X}$

Muñoz-Mora, J. C., Tobón, S., \& D'Anjou, J. W. (2018). The Role of Land Property Rights in the War on Illicit Crops: Evidence from Colombia. World Development, 103, 268-283. https://doi.org/10.1016/j.worlddev.2017.10.021

Nadelmann, E. A. (1988). U.S. Drug Policy: A Bad Export. Foreign Policy, 70, 83-108.

National Drug Intelligence Center. (2011). National Drug Threat Assessment 2011. https://doi.org/10.1037/e618352012-001

Newman, D. A. (2014). Missing Data: Five Practical Guidelines. Organizational Research Methods, 17(4), 372-411. https://doi.org/10.1177/1094428114548590 
SAENZ BARILLA New Approaches to U.S. Drug Policy

Niskanen, W. A. (1992). Economists and Drug Policy. Carnegie-Rochester Conference Series on Public Policy, 36, 223-248.

Office of National Drug Control Policy (ONDCP). (2011). FY 2012 Budget and Performance Summary: Companion to the National Drug Control Strategy.

Office of National Drug Control Policy (ONDCP). (2013). FY 2014 Budget and Performance Summary: Companion to the National Drug Control Strategy.

Office of National Drug Control Policy (ONDCP). (2014). FY 2015 Budget and Performance Summary: Companion to the National Drug Control Strategy.

Office of National Drug Control Policy (ONDCP). (2016). National Drug Control Strategy: Data Supplement 2016.

Office of National Drug Control Policy (ONDCP). (2018). National Drug Control Strategy. Retrieved June 5, 2017, from https://obamawhitehouse.archives.gov/ondcp/policy-andresearch/ndcs

Organization of American States (OAS). (2013a). Drugs and Development. In The Drug Problem in the Americas.

Organization of American States (OAS). (2013b). Drugs and Security. In The Drug Problem in the Americas.

Organization of American States (OAS). (2013c). Legal and Regulatory Alternatives. The Drug Problem in the Americas. https://doi.org/10.1017/CBO9781107415324.004

Organization of American States (OAS). (2013d). Production and Supply of Drugs, Pharmaceuticals, and Chemical Precursors. In The Drug Problem in the Americas.

Portland State University. (2009). Country Geography Data. Retrieved September 20, 2017, from https://www.pdx.edu/econ/country-geography-data

Porter, M. E. (1990). The Competitive Advantage of Nations. Harvard Business Review, 68(2), 73-91.

Quah, D., Collins, J., Atuesta, L., Caulkins, J., Csete, J., Drucker, E., ... Ziskind, J. (2014). Ending the Drug Wars. Report of the LSE Expert Group on the Economics of Drug Policy. Retrieved from http://www.lse.ac.uk/ideas/publications/reports/pdf/lse-ideas-drugs-reportfinal-web.pdf

Redford, A., \& Powell, B. (2016). Dynamics of Intervention in the War on Drugs: The Buildup to the Harrison Act of 1914. Independent Review, 20(4), 509-530. https://doi.org/10.2139/ssrn.2533166

Reuter, P. (1991). On the Consequences of Toughness. In E. Lazear \& M. Krauss (Eds.), Searching for Alternatives (pp. 138-164). Hoover Institution Press.

Reuter, P. (1992). The Limits and Consequences of U.S. Foreign Drug Control Efforts. The Annals of the American Academy of Political and Social Science, 521, 151-162.

Reuter, P., \& Kleiman, M. A. R. (1986). Risks and Prices: An Economic Analysis of Drug Enforcement. Crime and Justice, 7, 289-340. https://doi.org/10.1086/449116 
Roberts, M., Trace, M., \& Klein, A. (2004). Law Enforcement and Supply Reduction.

Rosen, L. W. (2015). International Drug Control Policy: Background and U.S. Responses.

Rugman, A. M., \& Gestrin, M. (1993). The Strategic Response of Multinational Enterprises to NAFTA. The Columbia Journal of World Business, 28, 18-29.

Saenz, M., \& Thompson, E. (2017). Gender and Policy Roles in Farm Household Diversification in Zambia. World Development, 89, 152-169. https://doi.org/10.1016/j.worlddev.2016.08.007

Siebert, H. (1997). Labor Market Rigidities: At the Root of Unemployment in Europe. Journal of Economic Perspectives, 11(3), 37-54. https://doi.org/10.1257/jep.11.3.37

Singh, T. (2010). Does International Trade cause Economic Growth? A Survey. The World Economy, 33(11), 1517-1564. https://doi.org/10.1111/j.1467-9701.2010.01243.x

Spergel, I. (1991). Youth Gangs: Problem and Response.

StataCorp. (2013). Stata Multiple-Imputation Reference Manual: Release 13.

StataCorp. (2017). Structural Equation Modeling Reference Manual, Release 15.

Sung, H. E. (2004). State Failure, Economic Failure, and Predatory Organized Crime: A Comparative Analysis. Journal of Research in Crime and Delinquency, 41(2), 111-129. https://doi.org/10.1177/0022427803257253

The Heritage Foundation. (2018). Index of Economic Freedom. Retrieved May 20, 2018, from http://www.heritage.org/index/explore?view=by-region-country-year

The World Bank. (2017a). World Development Indicators. Retrieved May 20, 2018, from http://databank.worldbank.org

The World Bank. (2017b). Worldwide Governance Indicators. Retrieved May 20, 2018, from www.govindicators.org

Thornton, M. (1991). Alcohol Prohibition Was a Failure. Policy Analysis. https://doi.org/10.1016/j.immuni.2008.03.009

Tolentino, P. E. (2001). From a Theory to a Paradigm : Examining the Eclectic Paradigm as a Framework in International Economics. International Journal of the Economics of Business, 8(2), 191-209. https://doi.org/10.1080/13571510110051496

UCLA: Statistical Consulting Group. (2018a). How Can I Estimate R-Squared for a Model Estimated with Multiple Imputed Data? Retrieved April 30, 2018, from https://stats.idre.ucla.edu/stata/faq/how-can-i-estimate-r-squared-for-a-model-estimatedwith-multiply-imputed-data/

UCLA: Statistical Consulting Group. (2018b). Multiple Imputation in Stata. Retrieved April 17, 2018, from https://stats.idre.ucla.edu/stata/seminars/mi_in_stata_pt1_new/

Uggen, C., \& Thompson, M. (2003). The Socioeconomic Determinants of Ill-Gotten Gains: Within-Person Changes in Drug Use and Illegal Earnings. American Journal of Sociology, 109(1), 146-185. https://doi.org/10.1086/ajs.2003.109.issue-1 
SAENZ BARILLA New Approaches to U.S. Drug Policy

United National Office of Drugs and Crime (UNODC). (2008). The Threat of NarcoTrafficking in the Americas. Retrieved from http://www.unodc.org/documents/data-andanalysis/Studies/OAS_Study_2008.pdf

United National Office of Drugs and Crime (UNODC). (2010a). Crime and Instability: Case Studies of Transnational Threats.

United National Office of Drugs and Crime (UNODC). (2010b). World Drug Report 2010. https://doi.org/10.1002/yd.20002

United National Office of Drugs and Crime (UNODC). (2011). World Drug Report 2011. https://doi.org/10.1007/s12117-997-1166-0

United National Office of Drugs and Crime (UNODC). (2015). World Drug Report 2015.

United National Office of Drugs and Crime (UNODC). (2017a). UNODC Statistics. Retrieved June 8, 2018, from https://data.unodc.org/

United National Office of Drugs and Crime (UNODC). (2017b). World Drug Report 2017: Global Overview of Drug Demand and Supply.

United National Office of Drugs and Crime (UNODC). (2017c). World Drug Report 2017: Market Analysis of Plant-Based Drugs.

United Nations. (2019). Annex of the World Drug Report 2019. Retrieved October 21, 2019, from https://wdr.unodc.org/wdr2019/en/maps-and-tables.html

United States Drug Enforcement Administration (DEA). (2020). The DEA Years. History. https://doi.org/10.1227/01.NEU.0000119577.21740.89

WGBH Educational Foundation. (2014). Thirty Years of America's Drug War: A Chronology.

Wooldridge, J. M. (2016). Introductory Econometrics (Sixth Edit). Boston, United States: Cengage Learning.

Youngers, C. A. (2013). The Drug Policy Reform Agenda in the Americas.

Youngers, C. A., \& Rosin, E. (Eds.). (2005). Drugs and Democracy in Latin America: The Impact of U.S. Policy. Boulder, Colorado: Lynne Rienner Publishers. 